DIW BERLIN

Discussion

Papers

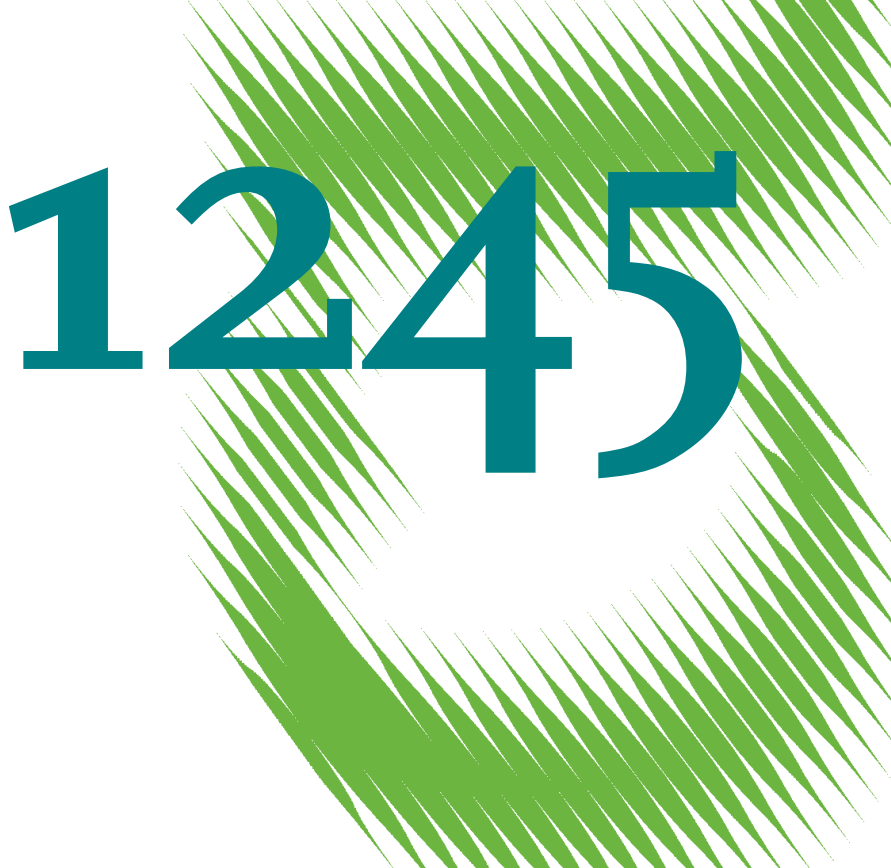

On the Path to Trade Liberalization

Political Regimes in International Trade Negotiations 
Opinions expressed in this paper are those of the author(s) and do not necessarily reflect views of the institute.

IMPRESSUM

(C) DIW Berlin, 2012

DIW Berlin

German Institute for Economic Research

Mohrenstr. 58

10117 Berlin

Tel. $+49(30) 89789-0$

Fax +49 (30) $89789-200$

http://www.diw.de

ISSN print edition $1433-0210$

ISSN electronic edition 1619-4535

Papers can be downloaded free of charge from the DIW Berlin website:

http://www.diw.de/discussionpapers

Discussion Papers of DIW Berlin are indexed in RePEc and SSRN:

http://ideas.repec.org/s/diw/diwwpp.html

http://www.ssrn.com/link/DIW-Berlin-German-Inst-Econ-Res.html 


\title{
On the Path to Trade Liberalization: Political Regimes in International Trade Negotiations
}

\author{
Florian Mölders \\ DIW Berlin ${ }^{1}$
}

September 2012

\begin{abstract}
The number of free trade agreements has increased substantially since 1980 despite efforts to promote multilateral trade liberalization. While there is evidence on the determinants of FTA formation, still little is known on the processing of trade agreements, particularly regarding the pre-implementation duration. This paper fills the research gap by using event data on the proposal, the negotiation, the signing, and the implementation of trade agreements. Duration analysis is employed to examine the connection between regime types and the lengths of the negotiation and the ratification stages. The results support the claim that higher levels of democratization and political constraints are associated with delays in the implementation of an agreement. This is primarily observable in the ratification stage. Moreover, I detect significantly prolonged negotiation talks and ratifications if the European Union participates.
\end{abstract}

JEL classification: F13

Keywords: Free trade agreements, International cooperation, Duration analysis

\footnotetext{
${ }^{1}$ Address: DIW Berlin, Mohrenstraße 58, 10117 Berlin, Germany. E-mail: fmoelders@diw.de. This paper was circulated before under the title "The Road to Trade Liberalization is paved with good Intentions - A survival analysis of trade negotiations". For helpful comments, I thank Ghassan Baliki, Ansgar Belke, Matthias Busse, Axel Dreher, Felix Groba, Daniel Kemptner, Adam Lederer, Christoph Moser, Paul Viefers, Georg Weizsäcker, seminar participants at DIW Berlin as well as participants at the "2012 Conference on Development Economics and Policy" of the German Economic Association in Bonn.
} 


\section{Introduction}

Despite the World Trade Organization's (WTO) effort to promote multilateral trade liberalization, there has been a surge in bilateral and multilateral free trade agreements (FTAs) instead. Consequently, the proliferation of these agreements encouraged the WTO to frame FTAs in terms of coherence instead of co-existence (WTO, 2011). While we have an idea of what sort of countries eventually enter into trade agreements, ${ }^{2}$ there is little known about what determines the duration prior to actual implementation. This is particularly important if the expectations of forward-looking firms (exporters) rely on credible information on the date of tariff removal to initiate investment and exporting operations. Just as in the case of FTA formation, I expect political factors, along with economic factors, to be important for pre-implementation decisions (Mansfield and Milner, 2012). In 2010, when the Nobel Prize was awarded to Liu Xiaobo, China postponed trade talks on the bilateral China-Norway FTA. ${ }^{3}$ This is an indication of the sensitivity of trade negotiations to differences in political regimes which forms a central part of this paper.

Durations from the start of the negotiations through implementation differ considerably: ranging from just under one year in the case of the Pan-Arab Free Trade Area to over ten years for the bilateral trade initiative between Panama and Chile. Fearon (1998) highlights the importance of strategic interactions between states when they decide whether to cooperate on an agreement. The findings suggest that lower costs of non-cooperation and more diverging expectations in the agreements' design lead to delays in implementation. When it comes to the evaluation of trade initiatives, most research focuses on ex-post analyses of the trade creating effects. In this respect, the gravity model has emerged as one of the most valuable tools as it allows for the inclusion of the most relevant explanatory variables and, at the same time, is bolstered by sound theoretical underpinnings.

The literature has so far missed out on the dynamics that go hand in hand with trade policy; specifically, the anticipation of trade liberalization offers an abundance of research questions. Burstein and Melitz (2011) analyze transition dynamics at the firm level in the

\footnotetext{
${ }^{2}$ See Baier and Bergstrand (2004); Mansfield et al. (2002); and Martin et al. (2010).

3 The Guardian, 2 December 2010. Available from http://www.guardian.co.uk/world/2010/dec/02/chinanorway-talks-nobel-peace-prize.
} 
course of trade liberalization by focusing on innovation activities that determine the decision to export and the trade volume prior trade liberalization. In a similar vein, Bergin and Lin (2012) empirically show that trade increments are triggered well ahead of the implementation of the European Monetary Union (EMU). In both papers, the authors refer to firm behavior as the leading driver to a trade increase, mainly triggered by a shift in expectations with respect to future profits in the foreign market. In this context, policy uncertainty is an issue in international economics that deserves more attention as it adds a new perspective to the interaction between the private sector and the policy level. Handley and Limão (2012) contribute to this debate by assessing Portugal's accession to the European Union (EU). Even though trade barriers were lifted well ahead of the formal accession the EU, trade creating effects only emerged after Portugal officially joined the bloc. ${ }^{4}$

The contribution of this paper lies in the documentation of determinants of the duration of trade negotiations, as well as the ratification stage, with a special focus on driving factors from the political spectrum. The results allow a better evaluation of the announcements of trade initiatives and thereby may help to reduce uncertainty involved in the interaction between firms and policymakers. Using a dataset with time-varying covariates, the determinants of the duration of FTA negotiations are found to be multi-dimensional, and not limited to economic factors. Political aspects, especially the levels of democratization and political constraints, are equally important. Existing literature does not address this dimension.

My findings suggest that bilateral trade agreements reflect significant faster negotiation processes as compared to agreements with more than two countries involved, even though this effect diminishes in the ratification stage - between signature of the agreement and enforcement of the liberalization measures. The same effect on the negotiation process is observed for countries that are more reliant on international trade. Further, countries that are members of the EU mirror significant delays that, as I will argue, may be based on additional provisions during negotiations (e.g. WTO-X) and coordination issues. I find support

\footnotetext{
${ }^{4}$ Handley and Limão (2012) interpret this as a sign of revealed uncertainty in the private sector as firms had to take into account a potential policy reversal.
} 
for the claim that political regime types play a major role in determining the implementation process: delays between signature and implementation are more likely if countries have more democratic political systems, even though this effect points in the opposite direction during the negotiation stage. A prolonging influence is observed during ratification for a higher level of political constraints for the executive power within a country, which is consistent with the (scarce) literature on this topic. The implications for policy from this research are manifold: First, if the fast finalization of trade negotiations with a single trading partner is a priority, countries should seek a bilateral agreement instead of a multilateral one. Second, democracy and the respective level of political constraints come at a cost: they are associated with longer ratification periods. Third: negotiation partners should be more patient between any stages of the implementation process if the EU takes part in the prospective FTA, as its participation indicates a lower probability of quickly closing trade deal. This may be due to attached WTO-X provisions in the negotiation stage as well as to the EU coordination process.

The paper is structured as follows: The following section reviews the respective literature on international trade and cooperation, while section three describes potential determinants for longer/shorter negotiation and implementation periods. The data and the econometric specifications are described in sections four and five respectively. Section six presents the results on the duration of the negotiation and ratification processes. Section seven concludes.

\section{Existing literature}

The objective of this section is to motivate the analysis of the negotiation and ratification durations with the recent work on transition dynamics of FTAs. The results of the majority of papers on the trade creating effects of FTAs lead to the conclusion that trade is triggered by the implementation of an agreement. ${ }^{5}$ While the literature on the ex-post trade effects of FTAs is exhaustive, there is substantial room for contributions that aim at investigating the accompanying effects of trade agreements. In this section I first give an overview on the discussion about anticipatory trade effects of FTAs. Since firms may only be induced to export prior to the actual lifting of trade barriers, given that the announcement of a common

\footnotetext{
${ }^{5}$ Examples include Frankel (1997) and Glick and Rose (2002).
} 
FTA is credible, we want to know what factors can lead firms to expect a slow or fast transition period between announcement and implementation. I then summarize the relevant body of literature that deals with duration analysis in the context of international treaties.

Since Freund and McLaren (1999) pointed out anticipatory effects of trade agreements, the notion of pre-implementation effects has been included in successive analyses. According to their results, trade adjustment led to anticipatory trade effects four years before countries officially joined the EU. Other contributions to the literature seem to affirm the presence of anticipatory trade effects of trade agreements. Results by Magee (2008) show that there is substantial anticipation prior to an agreement's implementation, if controlled for leads in a gravity model analysis. In a similar vein, Mölders and Volz (2011) analyze preimplementation effects from a different angle by focusing on the consecutive stages of implementation that an FTA runs through. Their results point toward the existence of anticipatory trade effects in the context of East Asian bilateral FTAs during the negotiation stage of an FTA.

Burstein and Melitz (2011) shed light into the transition dynamics of firms during trade liberalization. In their model, exporting decisions are driven by productivity dynamics. ${ }^{6}$ Since sunk costs, associated with the exporting decision, generate an option value of waiting, some firms may find it profitable to begin exporting after the announcement of future trade liberalization. ${ }^{7}$ Bergin and Lin (2012) make use of a dynamic stochastic general equilibrium model (DSGE) in order to identify pre-implementation trade effects for countries joining the EMU. Similar to Burstein and Melitz (2011), their results are based on the forward-looking behavior of firms reacting to news about future trade liberalization. The fact that the mere announcement of trade liberalization may not suffice to generate anticipatory trade effects can be pinned down to the credibility of such an announcement. Firms will only invest in the new trade opportunity if they expect the sunk costs to flow back in future revenues. Handley

\footnotetext{
${ }^{6}$ Burstein and Melitz (2012) point out that innovation activities increase after the announcement of future trade liberalization but prior to de facto liberalization. They argue that, as the costs of innovation are a convex function, firms will smooth their innovation activities across multiple periods.

${ }^{7}$ Other first-mover advantages are mentioned in Robinson et al. (1994) (on shaping of consumer tastes) and Bar-Illan and Strange (1996) (on time-to build investments).
} 
and Limão (2012) examines Portugal's accession to the EU. Prior to its formal inclusion into the trade bloc, trade preferences were already at the free-trade level for industrial goods. However, there was a substantial increase in trade flows after the accession was formally concluded. This stresses the importance of formal trade agreements for increasing credibility and exploiting the full scope of the trade potential.

With respect to the impact of regime types on cooperation at the country level, Mansfield et al. (2002) find that states which are classified as being more democratic have a good chance of successfully concluding FTAs. In a similar vein, Mansfield and Milner (2012) re-emphasize this claim with an additional focus on the role of veto players in the pre-implementation period of a trade agreement. When policy makers have to decide on whether to form an FTA, they compare the potential benefits (e.g. better economic performance via free trade) against the costs arising during the negotiation and ratification stages. More democratic countries are more likely to form an agreement, although the associated political constraints increase the costs (decrease the likelihood) of the respective ratification. Mansfield and Milner also analyze empirically the role of the number of veto players on delays during the ratification stage. In accordance to their model and the findings presented here, a greater number of veto players will make it more likely for ratification to be delayed.

The findings by Moser and Rose (2012) mirror the paper presented here in many respects, as the authors investigate the driving factors of the duration between the announcement of negotiations and the signing of the agreement. The authors focus on the economic determinants, thereby excluding potential driving forces from the political dimension. When it comes to the comparability of the results, I also find evidence for shorter durations due to fewer negotiation partners. In particular, bilateral FTAs are implemented significantly faster than multilateral counterparts. The paper by Baccini (forthcoming) focuses on the propensity of country-pairs to cooperate in a trade agreement as well as the length of the respective negotiation period for the case of North-South preferential trade agreements. The role of the level of countries' institutions is at the center of Baccini and these are analyzed with the World Bank Worldwide Governance Indicators. His findings suggest that a higher level of institutional quality is associated with shorter negotiation durations, aside from a higher probability of the formation of trade agreements. 
Simonelli (2011) investigates the determinants of the duration of the negotiation process of international multilateral agreements; limited to agreements on rules of war, arms control, terrorism, commodities and environment issues. She thereby excludes the sort of agreement that is the focus of my paper. ${ }^{8}$ The results show that as the number of countries increases, so does the length of the bargaining process, even though the number of participant countries should be quite large in order to reveal this impact. In contrast, Wong and $\mathrm{Yu}$ (2007) focus on the accession duration of potential member countries to the GATT/WTO. In particular, the authors emphasize the role of a country's level of democratization. In accordance with the predictions of Mansfield et al. (2002) with respect to the higher probability of FTA formation, if countries are more democratic, Wong and $\mathrm{Yu}$ find a statistically significant effect (shorter accession duration) of the democracy variable. In a similar vein, Davis and Wilf (2011) examine the duration from a country's independence until the application date for the WTO, as well as the respective negotiation time form application until formal membership. The authors confirm a shorter time until application to the WTO if countries are more similar in their levels of democracy.

Similar to the approach taken in section six of the present paper, but with regard to bilateral investment treaties (BITs), Haftel and Thompson (forthcoming) estimate the effect of the level of democracy and the political constraints on the duration of the ratification period between signature of an international agreement and the domestic process until the agreement is implemented. The authors control for various political and legal constraints that may influence the duration and find empirical support for a duration-increasing effect of political constraints of the executive. A greater number of veto players in the ratification process will make the process take longer. Likewise, more democratic governments need more time to implement a signed agreement.

In the following section, I motivate potential determinants that, according to the literature on international cooperation or FTA formation, may affect the length of trade negotiations.

\footnotetext{
${ }^{8}$ The data on agreements that Simonelli (2011) includes in her analysis range from 1864 through 2004. Only agreements that were actually signed are included in her analysis.
} 


\section{Theoretical considerations}

The main objective of this paper is to uncover the potential driving factors behind the duration of an FTA's road to implementation, with special emphasis on the levels of democracy and political constraints. The bargaining model by Fearon (1998) presents a good intuition for what determines the duration of the bargaining process in multilateral agreements. Assuming complete information for all players, his model suggests that countries have the choice between two alternate agreements $(x, y)$, which have a non-zero difference in present value: $|(x-y) / r|>0 .{ }^{9}$ Country one favors implementation of $x$ whereas country two favors $y$. The larger the difference in present value, the longer the duration before an agreement over either $x$ or $y$ is reached. Intuitively, this results from the opposing views concerning cooperation in a common agreement. In the case presented here, this could be translated into a scenario where one country favors liberalization in agricultural products, while the other lobbies for an exemption clause in this sector. In addition to potentially opposing starting points, both countries have opportunity costs (costs of non-cooperation) that are denoted by $c_{1}$ and $c_{2}$. These costs represent any non-generated income due to failed negotiations. Following Fearon, the lower the costs of non-cooperation for either country, the less likely any respective country is to abide by a non-favorable cooperation agreement. In a nutshell, the time until implementation increases for a higher distance between the countries' tastes for the alternate agreements of the participant countries and for lower cost of non-cooperation. For both types of variables, I find respective covariates, of political and economic nature.

Given that the present paper focuses on both the negotiation and ratification stages, it should be noted that I cannot expect the same determinants to exhibit the same influence on the respective durations. In the negotiation process, the policy interaction and opposing interest groups at the (between-) country level are central, whereas in the ratification stage, political constraints within each country gain influence. Even though between-country differences in the expected design of a future FTA are shaped by interests within each country, the decision-making process is expected to shift from the between- toward the within- country case if I move from negotiation to ratification (Mansfield and Milner, 2012: 57).

\footnotetext{
${ }^{9} r$ denotes the discount rate.
} 
In the following I give an overview on what factors may determine the duration of the negotiations and the time until successful implementation of trade agreements, given empirical and anecdotal evidence in the literature. The respective data sources for the following determinants can be found in the subsequent section.

\section{Political determinants}

In the literature, there is an abundance of papers on the effect of trade liberalization (e.g. via FTAs) on the bilateral trade volume. However it is only newer research that focuses on the stages prior to the implementation of such agreements. For example, Mansfield and Milner (2012) provide a thorough overview on the effect of political constraints and regimes on FTA formation. Even though they also focus on potential delays in the ratification stage due to an increase in the number of veto players, there is not yet an empirical analysis on both preimplementation periods: negotiation and ratification. The democratization level and the associated political constraints also potentially influence the duration process; I cannot expect that only economic factors are responsible for determining the amount of time that each stage takes. In the following, I introduce the two variables that are central for analyzing the role of political regimes in international trade cooperation.

Level of democracy: The more democratic a country, the more probable it is that it will form an FTA. Mansfield et al. (2002) provide evidence for this claim: democracies are per se more likely to form trade agreements. ${ }^{10}$ In contrast, autocracies are less likely to cooperate with countries of the opposing regime type. As an example that links the type of government with the process of cooperation, let us consider the trade agreements that involve the $\mathrm{EU}$ or the United States vis-à-vis developing countries. The EU, for example, demands considerable policy reforms in terms of human rights before negotiations can proceed to implementation. ${ }^{11}$ The United States, which has concluded a number of trade agreements,

${ }^{10}$ Lipson (2003) links democracies to the level of transparency and concludes that democracies generally provide more information and keep the policy process more open than other regime types. This comes at the cost of slower policy making. Hollyer et al. (2011) find supportive evidence for the claim that democracies are more transparent.

${ }^{11}$ As an example, consider the Cotonou Agreement (the successor of the Lomé Convention) that demands respect for human rights from its member states (UNCTAD, 2003). Trade agreements between the EU and developing countries further carry expectations regarding development policy and its impact (Makhan, 2010). 
also includes these kinds of provisions. ${ }^{12}$ The inclusion of governance clearly adds a new dimension to the negotiation process that has the potential to increase the complexity and, hence, the time until implementation. In accordance with both Haftel and Thompson (forthcoming) and Wong and $\mathrm{Yu}$ (2007), I control for the country-pair's level of democratization, as well as the difference thereof. ${ }^{13}$

Level of political constraints: Following the argumentation by Haftel and Thompson (forthcoming) and Mansfield and Milner (2012), I include the level of political constraints in the empirical analysis. Both works state that the more veto players that are involved, the longer ratification decisions take in the respective country and the less the executive can affect the implementation date. While Haftel and Thompsons' paper focuses on BITs, the intuition for controlling for this effect should also be self-evident in the context of FTAs. Mansfield and Milner (2012) find evidence for a delaying effect of the number of veto players in the ratification stage of FTAs. In principal, trade negotiators could adjust their positions during the negotiation stage such that they are more likely to gain support at home in order to ratify the trade agreement more easily. But, as Mansfield and Milner (2012) argue, such an approach is more likely to result in even more entrenched positions during the trade talks.

Based on this argumentation in favor of controlling for political variables in the empirical analysis, I derive the following hypotheses:

Hypothesis 1: The greater the difference in the level of democratization of the countries involved, the longer it takes to reach an agreement. At the same time, more democratic economies should reflect shorter negotiation periods.

Hypothesis 2: The greater the political constraints, the longer the ratification period will last due to the higher number of veto players involved.

\footnotetext{
${ }^{12}$ See Hafner-Burton (2009).

${ }^{13}$ Another channel through which democracy may influence the implementation process of trade agreements is driven by electoral motives. Conconi et al. (2012) show that as elections come closer, legislators in the US tend to vote more protectionist.
} 
Besides these hypotheses, which reflect the main research question of this paper, other determinants have the potential to drive both negotiation and ratification processes. In the following, I derive additional variables from the literature that are included in the empirical part of this paper.

FTA activity: Given that countries do not negotiate all of their trade agreements at the same point in time, the level of experience in FTA negotiations or the capacity for negotiating on trade issues with other countries, can be best approximated with the number of agreements in force for any given period. It may be expected that countries with more implemented FTAs have better capacities for trade negotiations and the respective ratifications, thus reflecting fewer delays.

Bilateral vs. multilateral agreements: Simonelli (2011) focuses on the number of negotiation partners at the bargaining table. Accordingly, as the number of states increases, so does the complexity involved in the process, e.g. due to the increasing number of items to negotiate over. ${ }^{14} \mathrm{~A}$ distinction between bilateral and multilateral trade agreements is a variable that stratifies the sample. We may expect that bilateral trade agreements are concluded more quickly.

WTO membership: Becoming a member of the WTO signals to investors and foreign policy makers that the regulatory framework (and government intervention) is, in parts, bound by the WTO guidelines and it offers the opportunity to lock-in reforms aimed at liberalization. Think of the most-favored-nation (MFN) clause that requires member countries to harmonize external tariffs. Membership further gives positive signals in terms of an open trade policy regime to investors in terms of credibility of policy reforms. ${ }^{15}$ With respect to the duration of FTA negotiations, membership in the WTO may have an ambiguous effect. On the one hand, it may lower the duration as it demonstrates experience in multilateral trade negotiations. On the other hand, the costs of non-cooperation supposedly decrease if membership in the WTO is the alternative to a failure in FTA negotiation/ratification. ${ }^{16}$ This would point toward longer durations. Furthermore, being a member of the WTO already

\footnotetext{
${ }^{14}$ See also Sebenius (1983).

${ }^{15}$ See Hoekman and Roy (2000) and Francois (1997).

${ }^{16}$ See Mansfield and Milner (2012: 4; 89).
} 
demands significant steps toward trade liberalization. An additional reduction of trade barriers is, consequentially then more difficult to negotiate over.

EU membership: In addition to the factors outlined so far, I include a dummy variable in the regression analysis for membership of the EU in the negotiation and ratification processes. This is due to its special role in the multilateral trading system, which includes the coordination of additional trade initiatives at the multilateral level with all EU member countries, as well as WTO-X provisions to be discussed in the negotiation stage, which may prolong the process. ${ }^{17}$

\section{Economic determinants}

The decision of countries to form an FTA may also reveal information on the pace of implementation. This assumption is guided by the studies of Baier and Bergstrand (2004) as well as Magee (2003) on the determinants of the formation of trade agreements. Although limited to economic determinants, the model by Baier and Bergstrand is proven to predict the majority of existing trade initiatives via country-pair characteristics (83.04 percent were correctly predicted by their model). When it comes to the employed method in their analysis, it is noteworthy that the authors rely on a dyadic dataset in order to derive their predictions. They treat the decision to enter an FTA as bilateral rather than multilateral by arguing that any country in a multilateral agreement has the power to veto, based on bilateral characteristics, which is analogous to the method I present in sections five and six.

Level of average trade barriers: The actual level of trade barriers (measured as the average tariff level), that country A imposes on imports from country $B$, is a proxy for the level of trade restrictions between both economies. FTAs aim at removing tariff and other barriers, and we may expect that negotiations for such liberalization measures last longer if the initial tariff level is high. Conversely, if the implementation date is also taken into account, a

\footnotetext{
${ }^{17}$ See Horn et al. (2009: vi) who, with respect to trade negotiations, state that “[...] European PTAs are marred by considerable legal inflation. They ambitiously cover a wide range of topics, going much beyond the multilateral commitments entered into by the partners within the framework of the World Trade Organisation, but they are mostly unenforceable - if not entirely devoid of substance. The Union, in other words, seems to be using trade agreements to promote its views on how countries of the world should be run, and it is able to enlist its trade partners to do this, albeit in a noncommittal or semi-committal way."
} 
duration-decreasing relationship with respect to higher tariff barriers may be interpreted as effective, but long-lasting negotiations, that lead to lower tariffs by the agreements' implementation date. In the 2007 World Trade Report (WTO, 2007: xxvi), it is stated that "[...] lengthy negotiations may be a sign of the system at work - not at fault."

Level of trade openness: The level of trade openness (measured as the ratio of exports in a countries' GDP) of a country reveals its dependence on the international exchange of goods. With reference to the costs of non-cooperation, as mention in Fearon (1998), any period foregone without trade liberalization refers to potential losses in firm revenue or any other benefit generated via an FTA. Countries with a higher exports-to-GDP ratio are, consequently, more likely to proceed more quickly through the implementation process. Therefore, the expected effect in the duration analysis is negative. ${ }^{18}$ On the other hand, FTAs are a long-term commitment. Therefore, investment and potential delay in the negotiation process should be taken into account as the costs of hasty compliance increase the longer the tariff concessions will remain in force.

Level of economic development: Trade theory based on the Heckscher-Ohlin $(\mathrm{H}-\mathrm{O})$ model tells us that countries specialize in goods, depending on the respective factor endowment (commonly capital and labor). Baier and Bergstrand (2004) employ the capital-labor ratio to estimate its effect on the probability of FTA formation. Their findings suggest that the higher the difference in the relative factor endowment, the more likely the formation of common trade agreement. The difference in per capita income levels is used as an indicator of the respective levels of economic development which approximates relative factor endowment. ${ }^{19}$ Negotiation durations may differ for country-pairs at different levels of economic development as they negotiate over a different set of trade restrictions customized to their respective trade basket. Additionally, the product of the country-pairs'

\footnotetext{
${ }^{18}$ Mansfield and Milner (2012) find that the level of trade openness is positively related to the probability of FTA formation.

${ }^{19}$ The relationship between the per-capita income level and the capital-labor ratio can be derived from the percapita production function $y=A k^{\alpha}$.
} 
level of economic development will be controlled for, in order to capture available capacities for trade negotiations. ${ }^{20}$

\section{Cultural and Geographic determinants}

Other variables that potentially interact with the countries' ability to smoothly cooperate and negotiate can be found in the cultural and geographic dimension. Common cultural peculiarities or customs may point toward a common history that, in most cases, involves routine in negotiation between both states.

Common language: This argumentation is akin to the motivation of the language variable in gravity estimations. Frankel (1997) argues that speaking a common language reduces the costs of doing business with the foreign country. Higher costs of doing business, due to a language barrier, imply higher costs for trade negotiations. We can expect the respective variable to have a negative effect on the duration (decrease the time until implementation).

Common border: In order to further control for standard gravity variables, I include a dummy that indicates contiguity. In gravity estimates, this variable has a positive effect on the bilateral trade volume due to lower transport costs. In the context presented here, I expect the contiguity variable to have a negative (shortening) effect as the frequency of political and economic interactions increases with countries that share a common border. Nevertheless, in some instances contiguity may indicate a higher probability of conflict, which would correlate with troubled interactions at the policy level and hence lengthen the duration until successful implementation. ${ }^{21}$

Bilateral distance: Similar to the dummy variable on contiguity, bilateral distances are included to refer to the geographical proximity among a country-pair. The predictions with respect to the effect on the negotiation and ratification are therefore ambiguous as well.

\footnotetext{
${ }^{20}$ Anecdotal evidence for the relevance of capacity in trade negations for the successful conclusion of FTAs is provided by the example of the Canada-CARICOM negotiations. Canada provided 2.5 Million CAN dollars to the Caribbean Regional Negotiating Machinery in order "[...] to strengthen its work in researching, consulting, preparing and negotiating the Caribbean's external trade agreements." BBC Worldwide Monitoring, 8 April 2008.

${ }^{21}$ See Vasquez (1995).
} 


\section{Data}

\section{Dependent variable}

The information on announcements for the respective FTAs was obtained from a variety of sources, including the online representations of the WTO, and the European Commission or the Asian Regional Integration Center (ADB, 2012). In other cases (e.g. the United States Singapore agreement), official documents, such as the text of the agreement's treaty, are reliable sources. Further, the LexisNexis database is a major source for newspaper articles and press releases. The events that are of most interest include the first mentioning (by an official of any participating state in the FTA) of a forthcoming trade initiative (first official proposal), the start of the negotiations, the end of negotiation talks, the signing of the agreement and the implementation of the FTA. As a matter of fact, most data is available for either the signing or the implementation of the agreement because the treaty (signing) and the actual lift of tariff barriers are well documented. In some cases, information on the exact date of an announcement or event could only be obtained by assessing contradictory sources. In these cases I opted for the earliest announcement in order to account for the fact that the first news article was potentially correct and that the other press releases were following up on it. ${ }^{22}$ Given the lack of information on some of the FTAs, as well as missing data for some of the explanatory variables, I can work with a maximum of 132 durations in the regression analysis, based on the days passed from the beginning of the trade negotiations until the agreements' implementation. ${ }^{23}$ In addition to the enforced trade agreements, data on "early announcements" of FTAs have been used to complement the dataset. These agreements are either in the negotiation or the ratification stage and still await signature or implementation. ${ }^{24}$

\footnotetext{
${ }^{22}$ Consider the example of the Global System of Trade Preferences among Developing Countries (GSTP), a multilateral initiative among nine developing countries. On August 28, 1977, a news article published a statement on the decision to establish a trade agreement in the future. On July $31^{\text {st }} 1982$, a proposal was made to begin negotiation talks among the potential member countries. As the first mentioning of a future agreement was made in 1977, I set this date to represent the proposal of the GSTP.

${ }^{23}$ Note that this also includes FTAs that have not yet been implemented or signed but are still under negotiation or ratification phases. See Table $A 2$ in the Appendix for a list of all FTAs for which dates are available.

${ }^{24}$ In total, I collected dates for 225 trade agreements, of which 35 are "early announcements" that await either finalization of negotiations, signature of implementation.
} 


\section{Explanatory variables}

GDP data (in current US-Dollars) were extracted from the World Bank World Development Indicators (World Bank, 2012), as well as data on respective population levels. Trade data (e.g. for the trade openness measure) were obtained from the World Integrated Trade Solution Database (WITS, 2012). The data on bilateral import tariffs between any two economies was found in the UNCTAD TRAINS database (UNCTAD, 2012). This variable is defined as the average level of import tariffs on total imports. ${ }^{25}$ In order to incorporate the nature of the democracy level in the analysis, I included data from the Polity IV project (Marshall and Jaggers, 2012). The project's polity2 variable reflects information on a country's democracy level (or autocracy level respectively). It ranges from -10 (autocracy) to +10 (democracy). Any number in between reflects democratic deficiencies. ${ }^{26}$ For the level of political constraints within a country, I make use of the POLCONIII index by Henisz (2010). Data on the membership in the WTO was obtained from the WTO website. ${ }^{27}$ The level of experience in implementing FTAs is measured as the number of implemented trade agreements in any given period. To control for geographic and historic characteristics, information on distance, contiguity and common languages are included. These variables take into account geographic and cultural proximity and were sourced from CEPII (2012). ${ }^{28}$

Note that there is reason for careful treatment of the level of democratization and the political constraints in the empirical analysis, as both measures are correlated. The polity2 index is partially constructed using the level of constraints at the executive level. In order to take this interaction into account in the empirical section, I estimate the respective models for each of the two variables separately and jointly.

\footnotetext{
${ }^{25}$ Calculated as: ((tariffs on imports from $B$ to $\left.A\right)+($ tariffs on imports from $A$ to $\left.\left.B)\right) / 2\right)$. Tariffs refer to the simple average of effectively applied import tariffs on total imports.

${ }^{26}$ A variable that denotes the level of checks and balances is included in ancillary regressions as robustness check (see Beck et al., 2001). As this did not contribute to the findings, the respective results are not included here, but are available from the author upon request.

${ }^{27}$ http://www.wto.org/english/thewto_e/whatis_e/tif_e/org6_e.htm

${ }^{28}$ According to CEPII, bilateral distance is calculated following the great circle formula, based on the most populous agglomerations of the respective countries.
} 


\section{Stylized facts}

The 123 enacted trade agreements studied here took between 316 and 4,144 days from the start of negotiation through implementation, averaging 3.58 years (1,310 days). ${ }^{29}$ The majority of FTAs are bilateral (66 out of 123), meaning that the initiative is limited to two countries. Any agreement that involves more than two countries is considered to be multilateral (57 FTAs). If the durations are differentiated according to the nature of the FTA, in terms of being bilateral or multilateral, we observe a considerable difference: negotiations of bilateral trade agreements took on average 1,188 days until successful implementation compared to 1,452 days for multilateral initiatives. This comparison does not yet allow for any conclusions but hints at what might drive the differences in durations. However, the significance of the respective mean differences also indicates that multilateral agreements reveal a more delays.

[Table 1 about here]

Alternative durations are also taken into account in the regression analysis. Table 1 depicts average amount of time between alternative events. Based on information about 108 FTAs, the time of the negotiation process amounts to an average of 748 days, which is considerably shorter than the aforementioned 1,310 days, in which the time until the implementation is additionally considered.

Interestingly, once the agreement is signed by the trading partners, it takes an additional 517 days to finally implement the provisions- which I refer to as the ratification stage. The least data is available for the event "Proposed", which denotes the first mentioning of a forthcoming trade agreement by an official of any participating country. From the 107 available events, we observe an average of 1,936 days (which translated into more than five years) for the time from the initial proposal until the agreement comes into force. Wherever possible, information about the number of negotiation rounds is included. These rounds reflect meetings by officials in order to discuss provisions for the FTA. On average it took just over seven rounds to finalize the negotiation processes, even though this number is subject

\footnotetext{
${ }^{29}$ The minimum and maximum refer to the multilateral Pan-Arab Free Trade Area and the bilateral PanamaChile FTA, respectively.
} 
to considerable variation: the ASEAN-Australia-New Zealand FTA e.g. took 16 rounds (and 1,276 days) compared to the negotiations between the EFTA and Serbia (two rounds and 45 days). ${ }^{30}$

The proliferation of trade agreements began to gain momentum around 2000, when multilateral trade negotiations were at a stalemate. ${ }^{31}$ Figure 1 describes the frequency of negotiations for FTAs that started in any given year, compared to the respective frequency of FTA implementations. Before the breakdown of WTO trade negotiations in 1999 in Seattle, we observe a noticeable number of negotiations that started during the 1990s. Between 1991 and 2010, 117 out of the 123 FTAs, which are included in my dataset, started their negotiation processes. The bars that indicate implementation follow at a mean distance of 1,079 days.

[Figure 1 about here]

Another interesting observation is derived from the comparison of the time period in which the negotiations of the FTAs started. In order to do so, the 123 agreements (time between start of the negotiations until implementation) are split into roughly two equally-sized groups according to the starting year of the negotiations. From 1991 through 2003, there were 61 events that reported such announcements, while between 2003 and 2010 there were 62 for agreements announced. The differences in the respective durations are sizeable: before 2003, negotiation durations averaged 1,508 days, whereas after it took 1,116 days, more than a year faster, for the potential free-trade partners to reach an agreement.

\section{Empirics}

This section motivates the econometric specification for the duration analysis. Central to this analysis is the survivor function, $S(t)$, which describes the probability of "survival" beyond period t. "Survival" in the context presented here refers to either not concluding the

\footnotetext{
${ }^{30}$ These two extremes potentially overstate the relation between the number of rounds and duration of the negotiation stage, as the pairwise correlation only amounts to 0.38 .

${ }^{31}$ Several other motives may have contributed to the understanding of the growth in bilateral and multilateral FTAs. Baldwin's (1993) domino theory, for example, shows how the costs of non-participation in an FTA increase the more that trading partners form common agreements.
} 
negotiation or not ratifying the FTA. The mirror image of the survivor function, $F(t)$, describes the cumulative probability that negotiations or ratifications have been concluded prior to period $t$. It follows that:

$$
S(t)=1-F(t)=P(T>t)
$$

Figure 2 depicts the survival graph for the trade initiatives with the example of duration between the start of negotiations and implementation. It describes the probability ( $y$-axis) of an FTA's process duration to be longer than $t$ days (on the $x$-axis). In this figure, the data used are not censored because the start date always refers to the announcement of the start of negotiations and end with the implementation of the respective FTA.

[Figure 2 about here]

A number of econometric specifications are available for the analysis of duration data. The popular semi-parametric Cox proportional hazards (PH) model does not specify any distribution for the conditional hazard rate (conditional probability of exit), in contrast to the parametric specifications that I focus on later. ${ }^{32}$ The model being unconstraint from any distributional form is its biggest advantage because it is sometimes cumbersome to determine whether the hazard is constant (in which case an exponential distribution is implied) or monotonically increasing or decreasing, which would demand the Weibull distribution. The Cox model implies the PH assumption:

$$
\frac{h\left(t \mid x(t)_{i}\right)}{h\left(t \mid x(t)_{j}\right)}=\frac{\exp \left(x(t)_{i} \beta_{x}\right)}{\exp \left(x(t)_{j} \beta_{x}\right)}
$$

In general, this formula states that the ratio of the hazards of individuals $i$ and $j$ (and respective time-varying characteristics $x(t)_{i}$ and $\left.x(t)_{j}\right)$ is constant and therefore independent of $t$. In the context presented here, this assumption implies that, given a treatment (e.g. bilateral compared to multilateral FTA), the ratio of the conditional

\footnotetext{
${ }^{32}$ The Cox proportional hazards model is considered semi-parametric because the covariates enter the regression in a linear fashion, but no assumption is made for the baseline hazard.
} 
probability of implementation in any period is constant. Graphically, this translates into parallel hazard rates.

In contrast to the Cox model, parametric models, such as the exponential, Weibull or loglogistic model, assume a distribution for the baseline hazard. The correct model can be obtained by estimating the gamma model that puts the fewest assumptions on the underlying distribution and then perform tests on the respective parameter estimates that come out of the regression. ${ }^{33}$

A method that does not rely on the $\mathrm{PH}$ assumption is the accelerated failure time (AFT) model. It focuses on the survival function and therefore allows a direct interpretation for the effect of the coefficients on the survival time. The AFT model carries the name "accelerated" because we are no longer bound to the $\mathrm{PH}$ assumption. Instead changes in the covariates may now increase or decrease the probability of failure along the durations (Orbe et al., 2002). Key to understanding the difference between the AFT and the PH models is that the coefficients of the AFT model measure elasticities (given that the covariates are also measured in logs). The survival graphs of two distinct characteristics may then be shifted non-proportionally and reveal increasing or decreasing distances (differences in probabilities) between them. In our context, this may imply that the effect of having a bilateral instead of a multilateral FTA increases or decreases according to the value on the $x$ axis (T). Figure 3 depicts this example: The survival function is plotted according to the type (bilateral/multilateral) of any given trade agreement. Two noticeable observations need further attention. First, the probability of observing no successful implementation beyond $t$ is higher for trade agreements with more than two trading partners. Let us consider the probability for not observing implementation prior to day 1,000: if the FTA is bilateral, this probability is just above $50 \%$, whereas for multilateral initiatives the respective figure is set around $75 \%$. This lends support to the hypothesis that as more countries are involved in the

\footnotetext{
${ }^{33}$ The gamma distribution nests the Weibull as well as the exponential model depending on the parameter values of the baseline hazard. The exponential model e.g. demands a conditional probability of implementation that is constant over time; an assumption that is violated by my data. The difference between the log-logistic and the Weibull model is that the former allows for a non-monotonically increasing or decreasing hazard, compared to the latter model which assumes monotonic hazards. See Cleves et al. (2008: 270) for the respective approach.
} 
negotiation of an agreement, the longer it will take to close the negotiations. Second, the two curves in the survival graph do not tend to support the $\mathrm{PH}$ assumption, as they cross for very short and long durations. ${ }^{34}$

[Figure 3 about here]

The results of the log-logistic model, similar to the empirical analysis of the duration of the ratification phase in Mansfield and Milner (2012), are discussed in the following section. From the diagnostic tests performed, I can assume that either the Weibull or the log-logistic model in AFT form best matches the demand of the data, due to duration-dependent survival probabilities. Estimation of the parametric gamma model provides information that the Weibull model may be a candidate for the parametric approach. ${ }^{35}$ However, due to convergence issues in the computation of the regressions in section 6,1 opt for the estimation using the log-logistic distribution instead of the Weibull. The log-logistic distribution is easily modified to cope with time-varying covariates. ${ }^{36,37}$ This is particularly important as the dataset is constructed to allow for changes in the income or democracy levels for example. Note that a misspecification of the estimated model in terms of the distributional assumptions may severely bias the results, since the assumption of a monotonic hazard in the presence of a non-monotonic hazard may lead to the confirmation of unobserved heterogeneity. The decreasing hazard for higher time-observations will then be based on frailty of the individuals (in our context: country-pairs).

For the estimation, I make use of country-pair data that allows for taking into account a much wider range of information than alternative methods. Any country in the prospective FTA has the potential to prolong the implementation based on any other participant

\footnotetext{
${ }^{34}$ Numerically, a violation of the PH assumption was checked globally and confirmed (using Stata's estat phtest command). See Figure A1 in the Appendix for a test of the PH assumption based on Schoenfeld residuals.

${ }^{35}$ More precisely, the kappa value in the regressions based on the gamma distribution is estimated to be significantly different from zero while In_sigma is significantly different from 1.

${ }^{36}$ See Wooldridge (2002) and Bergstrand et al. (2010) for the duration analysis of the formation of FTAs using the log-logistic distribution.

${ }^{37}$ The Weibull model does not allow frailty or shared frailty estimations to be computed without reflecting problems in convergence, even if gamma frailty is replaced by inverse Gaussian.
} 
country. An alternative would be to make use of FTA specific information gathered from individual country data. This proves to be cumbersome in the regression analysis as measures of dispersion (average difference in per-capita GDPs, variation in trade openness etc.) do not sufficiently capture the available information. ${ }^{38}$ Therefore, I opt for the dyadic approach, following Baier and Bergstrand (2004) and Bergstrand et al. (2010). The latter also uses country-pair data for the FTA specific dependent variable in the analysis on the duration until the implementation of a trade agreement. Baier and Bergstrand (2004) make use of a dyadic dataset as any country may be able to veto the implementation and thereby exercise the power to halt the initiative.

A dataset with time-varying covariates is employed to fully incorporate the time-varying information involved in the majority of explanatory variables. This allows for a better evaluation of the effects of economic and political determinants because the duration from negotiation to implementation easily exceeds three years. An analysis based on timeconstant covariates (e.g. fixed at the date of the start of negotiations) would neglect a significant amount of information.

I try to control for unobserved heterogeneity via the shared frailty model. In addition to a given set of included covariates, the frailty model includes a multiplicative term in the hazard function. It is thereby similar to a random effects model which also controls for unobserved heterogeneity, given that the unobserved factor is uncorrelated with the included regressors. ${ }^{39}$ If we assume that all country-pairs are homogeneous conditional on all the regressors included in the model, the hazard function may be correctly specified using some distribution. If, however, some individuals are frailer than others, the hazard function may underestimate the degree of positive duration dependence. I assume that the unobserved heterogeneity is common at the FTA level, meaning that unobserved effects on the negotiation and ratification duration are common for all potential FTA members. The distribution of the error term in AFT models is adjusted to fit the nature of the duration data. Note that some of the variables in the following regression analysis are transformed into

\footnotetext{
${ }^{38}$ It is problematic to decide on how to include and aggregate variables like common language.

${ }^{39}$ Alternatively, one could implement a fixed-effects model that controls for the shared frailty factor in the regression.
} 
logs, such that the interpretation of the coefficients differs, compared to non-transformed covariates.

One additional potential source of bias is sample selection. This would be problematic if observations based on the dependent variable are chosen, which cannot be ruled out as only FTAs that have been implemented are considered in addition to those which are still in their negotiation or ratification stages ("early announcements"). We consequently do not observe failed implementations. Furthermore, it could be the case that treatment is based on unobservables that could also influence the outcome variable. In order to control for unobserved heterogeneity, the shared frailty parameter (at the FTA level) is included in the regression analysis, among other variables that have shown to influence the decision to form an FTA. ${ }^{40}$

\section{Results}

This section makes use of four different durations (dependent variables), each analyzed with three different specifications, taking into account the interplay between the level of democratization and the political constraints: the first regressions (Table 2) summarize the results of estimations based on the parametric log-logistic frailty model in AFT form for the time between the start of the negotiation until its end. Table 3 plots the results on the ratification period, from the signature of the agreement until its implementation. In Table 4, both periods are subsumed to represent the duration from the negotiation start until the enforcement of provisions. In Table A1 in the Appendix, you can find additional estimates for which the starting point of the duration is the first official proposal to form an agreement. $^{41,42}$

\footnotetext{
${ }^{40}$ Nevertheless, be advised that the major share of information for the negotiation and proposed events is sourced from newspaper articles and news releases available either in English or German. The resulting (potential) source of endogeneity is ignored, even though negotiation and ratification durations of FTAs, for which news was available in English or German may be different from those in other languages.

${ }^{41}$ As data on the proposal of an agreement is the least reliable, the respective results should be considered accordingly. Note that the absolute number of observations is the highest for the estimates based on the proposal as the starting point, as I make use of a dataset with time-varying variables. The total time span from proposal to the implementation is the longest (in years) for the duration.
} 
[Table 2 about here]

According to Table 2, countries that are negotiating a bilateral trade agreement are significantly faster than their counterparts negotiating multilateral agreements. Depending on the specification (inclusion of democracy, political constraints or both), bilaterals need about $38 \%$ to $50 \%$ less time to finish negotiations. The variable denoting the influence of the political regime type points into the direction of shorter trade talks for more democratic countries, whereas an increase in the number of veto players indicates delays. Also consistent with the argumentation outlined in section three, negotiations need more time if the EU is taking part in them. This may be either due to difficulties in coordination of trade policy across all member states or the attached non-trade related provisions that are part of EU trade agreements.

[Table 3 about here]

If we switch to the ratification stage (Table 3 ), the results change as this stage differs considerably from the trade negotiations. Being in a bilateral agreement no longer seems to affect the duration. From the variables that denote experience in FTA activity, namely the number of FTAs concluded, as well as WTO membership, there is evidence for an accelerating effect on the ratification period. This effect is only small in magnitude for the each individual existing concluded FTA but it reflects an increase in the ratification speed by almost four percent for every additional enforced agreement. If both countries are members of the WTO, I find a decrease in the duration by around $28 \%$, if controlled for both political regime type and constraints. The influence of the EU again indicates a longer time period, comparable to the negotiation stage, even though the effect seems to be reversed if not controlled for political constraints in the data. Due to the considerable decrease in observations if both political determinants are taken into account (data on political constraints is only available until 2007), conclusions from this observation have to be drawn

\footnotetext{
${ }^{42}$ Note that the (negative) Ln_gamma coefficient at the end of the Tables refers to the underlying log-logistic distribution and suggests a non-monotonic hazard. The value Theta represents the variance of the parameter which takes the unobserved heterogeneity into account. A highly significant estimate is evidence for the presence of heterogeneity.
} 
with caution. Different signs and significance levels may well arise through a different set of country-pairs and FTAs. Nevertheless, the respective coefficients for the political constraints and democracy variables suggest that an increase by one unit in the sum of the index denoting the democracy level is associated with a delay of $14 \%$. Similarly, doubling the value of the political constraints index reflects a slower implementation by around $39 \%{ }^{43}$ Differences along the political spectrum (country-pairs which are more dissimilar in terms of their democratization level) may also lead to delays in the ratification period. While the result based on the political constraints variable is in accordance to the findings by Haftel and Thompson (forthcoming) - more veto players lead to longer ratification durations - the respective effect of democracy is not. However, this observation is consistent with the claim made in section three: democracies may reflect slower policy making processes. Moreover, if countries are more open to trade, we can expect that FTAs are ratified faster, even though the corresponding coefficients are only partly significant. With respect to the level of trade restrictions among the country-pairs, another finding supports the assertion from section three that once I take the implementation date into account, lower import tariffs may be the result of more thorough, yet longer, negotiation and ratification periods triggering the decrease in import barriers. As I argue below, when it comes to the period between the start of the negotiations and the agreements' implementation, less ambitious approaches during negotiation (associated with shorter durations) may well lead to missing out on free trade

[Table 4 about here]

By combining the negotiation and ratification periods (Table 4), increased trade openness again indicates a shorter time period from the start of the negotiation process until the final implementation of the trade agreement. Similarly, WTO member states show a significantly shorter time until the agreements are implemented, even if both measures from the political spectrum are controlled for. Interestingly, and in line with the theoretical predictions, the coefficient for the level of economic development now becomes significantly negative, pointing toward a faster process for higher income country-pairs. This effect seems to be driven by the ratification stage (Table 3 ), whose results also pointed in this direction. Other determinants that only change marginally in their magnitude (vis-à-vis the ratification stage)

\footnotetext{
${ }^{43}$ Note that the index for political constraints is measured in logs whereas the polity2 index is not.
} 
and with respect to the sign are the EU member and political variables, even though the coefficient for the sum of the polity 2 index decreases considerably and even becomes insignificant, mirroring the fact that the effect on the ratification duration is diluted by the negotiation period. Unaltered is the message conveyed by the level of trade barriers: Higher import tariffs for goods traded among country-pairs are associated with shorter negotiation and ratification periods. Note that this effect may be due to reversed causality. As I make use of time-varying covariates (including import tariffs), a longer negotiation period may well be associated with higher initial import tariffs that, by the end of the implementation, are lowered considerably due to the negotiations. This implies that, once I take the implementation period into account, higher trade barriers can be a consequence of hasty trade negotiations. That claim is also supported by Table A1, which takes the first official proposal of an FTA as the starting point of the duration into account.

\section{Conclusion}

Trade agreements are characterized by their heterogeneity in a number of dimensions: from the coverage of goods, their effect on the bilateral trade volume, to the duration of the negotiation and ratification processes. Against the background of transition processes of firms in anticipation of a trade agreement, this paper focuses on the duration from initial announcement to implementation of FTAs. I make use of a dataset with time-varying covariates that covers officially notified FTAs for which the dates on the proposal, the start/end of negotiations, the signing and the implementation are available.

From the information on the available agreements, there is supportive evidence that both economic and political determinants matter for the duration of the negotiation process. After controlling for unobserved heterogeneity in the regression analysis, I find that bilateral agreements reflect shorter negotiation processes. This finding is consistent with Moser and Rose (2012) as well as Simonelli (2011). The complexity of the agreements' design seems to increase with the number of potential trading partners at the bargaining table. When it comes to anticipatory trade effects via FTAs, this result also relates to the findings of Mölders and Volz (2011), who claim that the negotiation stage of bilateral trade agreements already reflects positive trade-creating effects. This may be due to the (anticipated) faster negotiation process of bilateral FTAs. 
The effect of the country-pairs' democratization and political constraints levels on the ratification duration points toward a prolonging effect, which partly supports the finding of Haftel and Thompson (forthcoming), who claim that a higher level of checks and balances (prevalent in more democratic countries) significantly prolongs the respective durations for bilateral investment treaties. In a similar vein, Mansfield and Milner (2012) show that more veto players are associated with a delay in ratification in the case of FTAs. This result is confirmed by my data. The findings further suggest that more democratic states are more likely to finish trade negotiations faster, which is in line with the claim that these types of countries cooperate more easily. Therefore, regime types seem to matter for the processing of trade agreements.

The results associated with the effect of higher import tariffs are surprising at first sight, but point toward a need for lengthy implementation periods for high tariff cuts. This is in line with the assertion that negotiation partners are working longer in order to arrive at lower trade barriers. ${ }^{44}$ I further observe that trade openness is associated with shorter ratification periods. Similarly, the effect for WTO members and more active FTA countries also indicates significantly shorter processes for the same duration. It could be the case that better capacities and more experience in implementing FTAs can be the driving factor behind this result.

Consistent with the prediction outlined in section three, once the EU is involved, negotiations as well as ratifications reveal a significantly longer negotiation period, compared to FTAs with less demanding partners. Alongside the higher cooperation costs due to the high number of stakeholders at the negotiation table - WTO-X provisions such as human rights may divert from traditional trade policy measures and have the potential to prolong talks.

The results presented here support the hypothesis that costs of non-cooperation as well as coordination costs matter for the duration until the implementation of an FTA. It should be noted that the results do not imply causality of the respective variables of interest, as there

\footnotetext{
${ }^{44}$ See WTO (2007: xxvi).
} 
might be other determinants driving both the duration and the covariates. However, based on the literature on FTA determinants and international cooperation and through the application of the frailty model, I try to control for as many influences as possible.

The connection to determinants that drive anticipatory trade effects that emerge prior to the actual implementation of an agreement deserves further attention in future research as it matters for the evaluation of the effects of policy uncertainty on the private sector. A starting point would be to investigate whether the determinants, which are responsible for shortening the negotiation/implementation process of trade agreements, also influence firm exporting decisions via trade anticipation. On a different note, and related to Conconi et al. (2012), trade negotiations are potentially influenced by electoral cycles and the respective legislators' time in office. As this is especially important for democracies, an analysis of the negotiation and ratification processes against the electoral background of the policy maker is of interest. 


\section{References}

ADB, 2012. Asia Regional Integration Center. Asian Development Bank, Jakarta. Available from http://aric.adb.org/.

Baccini, L., forthcoming. Cheap talk: Transaction costs, quality of institutions, and trade agreements. European Journal of International Relations.

Baier, S., Bergstrand, J., 2004. Economic determinants of free trade agreements. Journal of International Economcis 64, 29-63.

Baldwin, R., 1993. A Domino Theory of Regionalism. NBER Working Paper 4465. National Bureau of Economic Research, Cambridge, Mass.

Bar-Illan, A., Strange, W., 1996. Investment Lags. American Economic Review 86, 610-622.

Beck, T., Clarke, G., Groff, A., Keefer, P., Walsh, P., 2001. New Tools in Comparative Political Economy: The Database of Political Institutions. World Bank Economic Review 15, 165 176.

Bergin, P., Lin, C.-Y., 2012. The Dynamic Effects of Currency Union on Trade. Journal of International Economics 87, 191-204.

Bergstrand, J., Egger, P., Larch, M., 2010. Economic Determinants of the Timing of Preferential Trade Agreement Formations and Enlargements. Unpublished Manuscript, University of Notre Dame.

Burstein, A., Melitz, M., 2011. Trade Liberalization and Firm Dynamics. Unpublished Manuscript, UCLA, Los Angeles.

CEPII, 2012. CEPII Geodesic Distances. Centre d'Etudes Prospectives et d'Informations $\begin{array}{llll}\text { Internationales, } & \text { Paris. Available from }\end{array}$ http://www.cepii.fr/anglaisgraph/bdd/distances.htm.

Cleves, M., Gutierrez, R., Gould, W., Marchenko, Y., 2008. An Introduction to Survival Analysis Using Stata. Stata Press, College Station, TX.

Conconi, P., Facchini, G., Zanardi, M., 2012. Policymakers' Horizon and Trade Reforms:The Protectionist Effect of Elections. CEPR Discussion Paper 8561, Centre for Economic Policy Reseach, London.

Davis, C., Wilf, M., 2011. Joining the Club: Accession to the GATT/WTO. Unpublished Manuscript, Princeton University. 
Fearon, J., 1998. Bargaining, Enforcement, and International Cooperation. International Organization 52, 269-305.

Francois, J., 1997. External Bindings and the Credibility of Reform, in: Galal, A., Hoekman, B. (Eds.), Regional Partners in Global Markets. Centre for Economic Policy Research, London.

Frankel, J., 1997. Regional Trading Blocs in the World Economic System, Peterson Institute for International Economics, Washington D.C.

Freund, C., McLaren, J., 1999. On the Dynamics of Trade Diversion: Evidence from Four Trade Blocs. International Finance Discussion Papers Vol. 637, New York Board of Governors of the Federal Reserve System and Columbia University.

Glick, R., Rose, A., 2002. Does a currency union affect trade? The time-series evidence. European Economic Review 46, 1125-1151.

Gutierrez, R., 2002. Parametric frailty and shared frailty survival models. Stata Journal 2, 2244.

Hafner-Burtoforthcomingn, E., 2009. Forced to Be Good: Why Trade Agreements Boost Human Rights, Cornell University Press, Ithaca, NY.

Haftel, Y., Thompson, A., forthcoming. Delayed Ratification: The Domestic Fate of Bilateral Investment Treaties. International Organization.

Handley, K., Limão, N., 2012. Trade and Investment under Policy Uncertainty: Theory and Firm Evidence. NBER Working Paper No. 17790, National Bureau of Economic Research, Cambridge, Mass.

Henisz, W., 2010. Political Constraint Index (POLCON) Dataset. Available from http://wwwmanagement.wharton.upenn.edu/henisz/.

Hoekman, B., Roy, J., 2000. Benefiting from WTO Accession and Membership, in: Hoekman, B., Zarrouk, J. (Eds.), Catching up with the Competition - Trade Opportunities and Challenges for Arab Countries. University of Michigan Press, Ann Arbor, pp. 307-324.

Hollyer, J., Rosendorff, P., Vreeland, J., 2011. Democracy and Transparency. Journal of Politics 73, 1191-1205.

Horn, H., Mavroidis, P., Sapir, A., 2009. Beyond the WTO? An anatomy of EU and US preferential trade agreements. Bruegel Blueprint Series 7, Brussels European and Global Economic Laboratory. 
Lipson, C., 2003. Reliable Partners: How Democracies Have Made a Separate Peace, Princeton University Press, Princeton, NJ.

Magee, C., 2008. New measures of trade creation and trade diversion. Journal of International Economics 75, 349-362.

Makhan, D., 2010. Coordinating EU trade and development policy-making in a new context. Trade Negotiations Insights 2, 1-3.

Mansfield, E., Milner, H., Rosendorff, P., 2002. Why Democracies Cooperate More: Electoral Control and International Trade Agreements. International Organization 56, 477-513.

Mansfield, E., Milner, H., 2012. Votes, Vetoes, and the Political Economy of International Trade Agreements, Princeton Universtiy Press, Princeton, NJ.

Marshall, M., Jaggers, K., 2012. Polity IV Project Database. Available from http://www.systemicpeace.org/inscr/inscr.htm.

Martin, P., Mayer, T., Thoenig, M., 2010. The geography of conflicts and free trade agreements. Unpublished Manuscript, Sciences-Po, Paris.

Melitz, M., 2003. The Impact of Trade on Intra-Industry Reallocations and Aggregate Industry Productivity. Econometrica 71, 1695-1725.

Mölders, F., Volz, U., 2011. Trade creation and the status of FTAs: empirical evidence from East Asia. Review of World Economics 147, 429-456.

Moser, C., Rose, A., 2012. Why Do Trade Negotiations Take So Long? KOF Working Paper 295, ETH Zürich.

Orbe, J., Ferreira, J., Núñez-Antón, V., 2002. Comparing proportional hazards and accelerated failure time models for survival analysis. Statistics in Medicine 21, 34933510.

Robinson, W., Kalyanaram, G., Urban, G., 1994. First-Mover Advantages from Pioneering New Markets: A Survey of Empirical Evidence. Review of Industrial Organization 9, 1-23.

Sebenius, J., 1983. Negotiation Arithmetic: Adding and Subtracting Issues and Parties. International Organization 37, 281-316.

Simonelli, N., 2011. Bargaining over International Multilateral Agreements: The Duration of Negotiations. International Interactions 37, 147-169.

UNCTAD, 2012. Trade Analysis Information System (TRAINS). United Nations Conference on Trade and Development, Geneva. Available from http://wits.worldbank.org/wits/. 
UNCTAD, 2003. Trade Negotiation Issues in the Cotonou Agreement. UNCTAD/DITC/TNCD/2003/2, United Nations Conference on Trade and Development, Geneva.

Vasquez, J., 1995. Why Do Neighbors Fight? Proximity, Interaction, or Territoriality. Journal of Peace Research 32, 277-293.

WITS, 2012. World Integrated Trade Solution. World Bank, Washington D.C. Available from http://wits.worldbank.org/wits/.

Wong, K., Yu, M., 2007. Democracy and the GATT/WTO Accession Duration. Unpublished Manuscipt, University of Hong Kong.

Wooldridge, J., 2002. Econometric Analysis of Cross Section and Panel Data, MIT Press, Cambridge, MA.

World Bank, 2012. World Development Indicators. World Bank, Washington D.C. Available from http://data.worldbank.org/data-catalog/world-development-indicators.

WTO, 2007. World Trade Report 2007 - Six decades of multilateral trade cooperation: What have we learnt?, World Trade Organization, Geneva.

WTO, 2011. World Trade Report 2011 - The WTO and preferential trade agreements: From co-existence to coherence, World Trade Organization, Geneva. 


\section{Figures}

Figure 1: Frequencies of events, Negotiations start (white) and trade agreements are implemented (black)

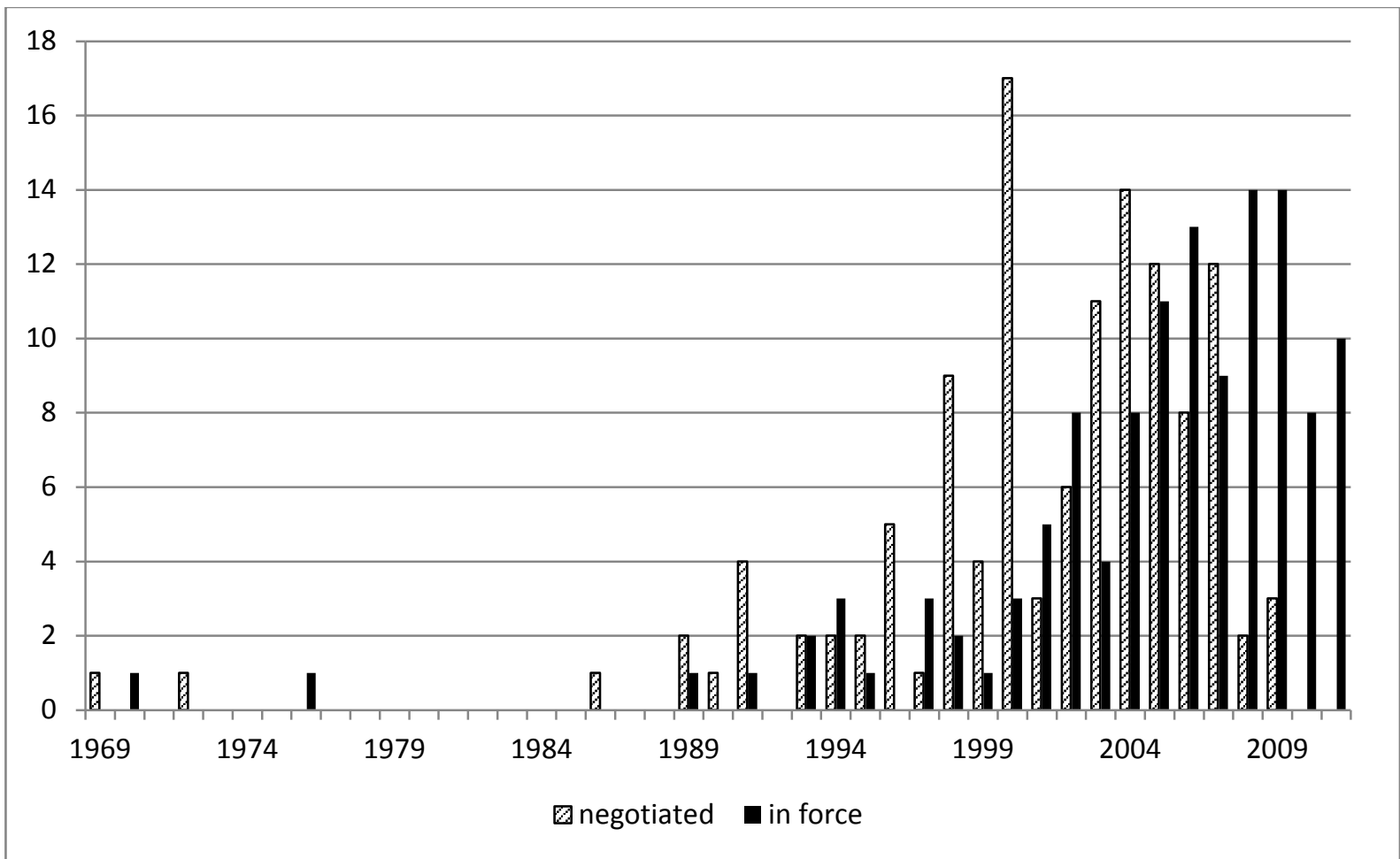

Notes: Only FTAs for which a date of the start of the negotiations and the implementation date were available are included in this Figure. 
Figure 2: Survival estimate: Duration from launch of negotiations until implementation

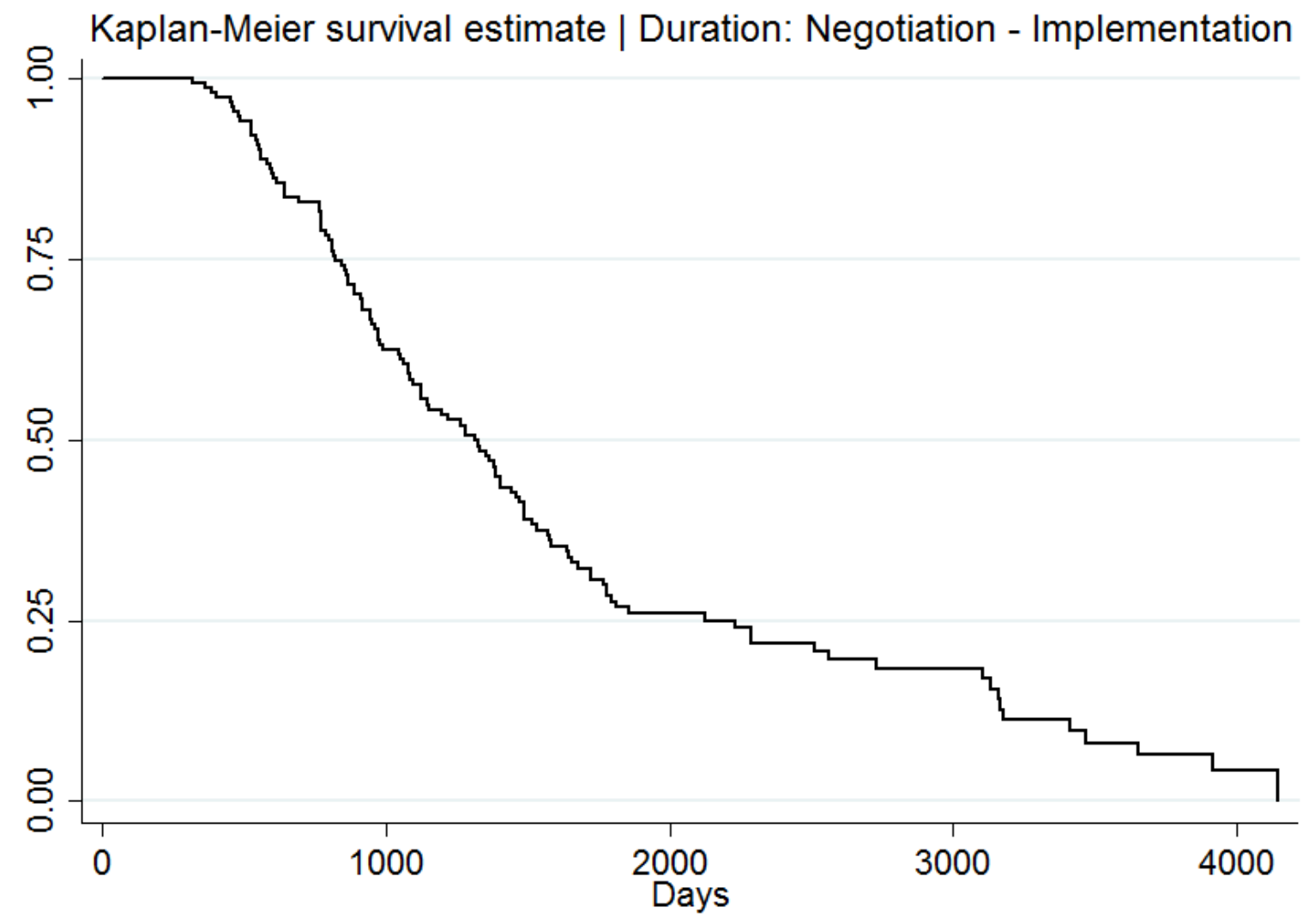

Notes: Figure includes only FTAs for which both date of the start of negotiations and enforcement are available; $x$-axis denotes duration time in days from start of negotiations; $y$-axis denotes the probability of implementation after day $t$. 
Figure 3: Survival estimate: Duration from launch of negotiations until implementation, by type of FTA (bilateral/multilateral)

Kaplan-Meier survival estimates | Duration: Negotiation - Implementation, BTA(0/1)

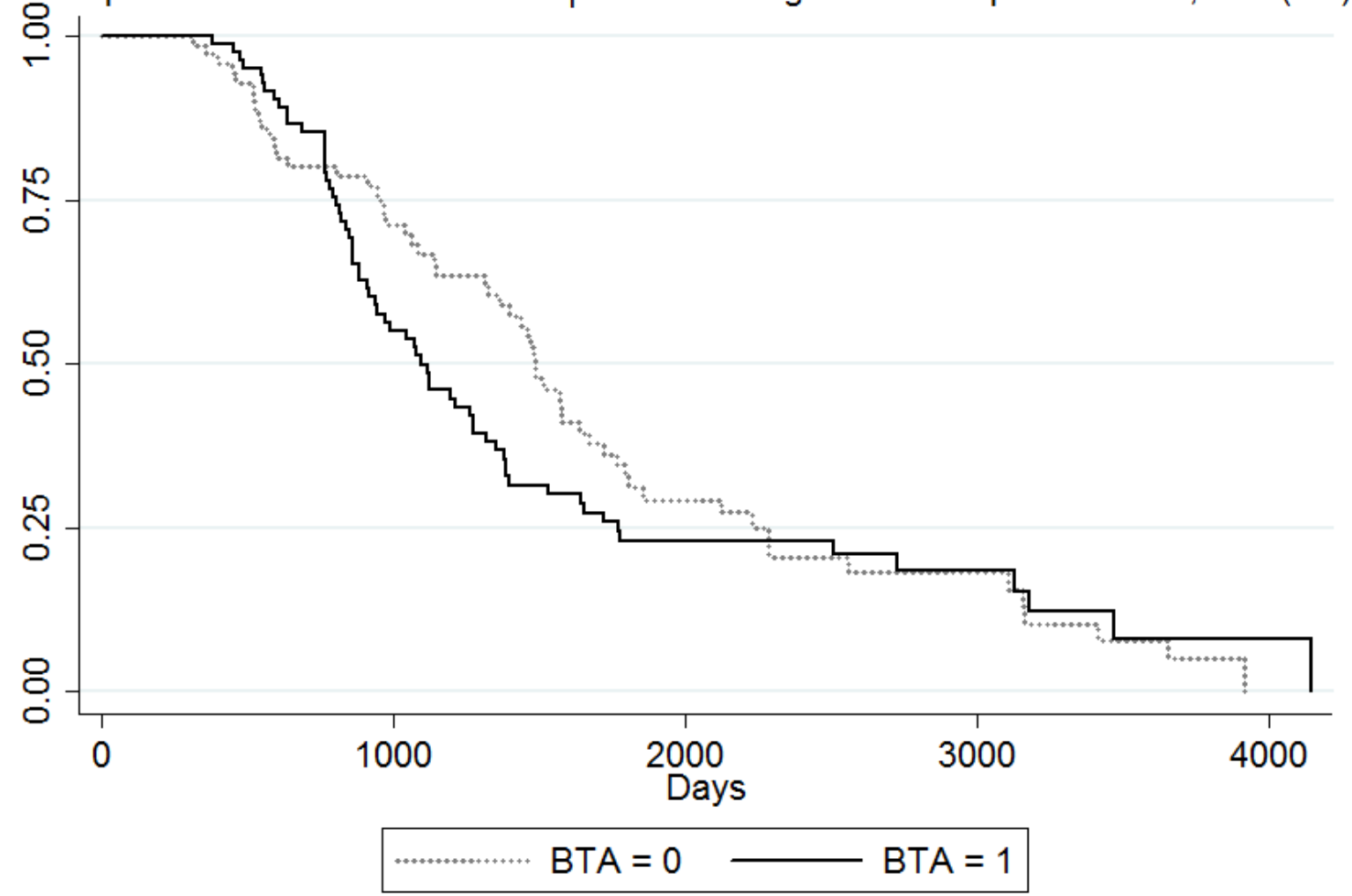

Notes: $x$-axis denotes duration time in days; $y$-axis denotes the probability of implementation after day $t$; stratified by FTA type: BTA=1 if bilateral agreement, BTA=0 otherwise.

\section{Tables}

Table 1: Average number of days between events

\begin{tabular}{lccccc}
\hline \hline $\begin{array}{l}\text { Time } \\
\text { between... }\end{array}$ & $\begin{array}{l}\text { Negotiation: } \\
\text { start-end }\end{array}$ & $\begin{array}{l}\text { Negotiation- } \\
\text { Signing }\end{array}$ & $\begin{array}{l}\text { Negotiation- } \\
\text { Implementation }\end{array}$ & $\begin{array}{l}\text { Signing- } \\
\text { Implementation }\end{array}$ & $\begin{array}{l}\text { Proposal- } \\
\text { Implementation }\end{array}$ \\
\hline $\begin{array}{l}\text { Number of } \\
\text { days }\end{array}$ & 748 & 852 & 1,310 & 517 & 1,936 \\
\hline $\begin{array}{l}\text { Information } \\
\text { based on \# } \\
\text { of FTAs }\end{array}$ & 108 & 129 & 123 & 188 & 107 \\
\hline \hline
\end{tabular}

\section{Memo:}

Average \# of negotiation

7.17

rounds

Notes: "Negotiation: start-end" refers to the duration from the start of negotiations until the end; "Negotiation-Signing" refers to the duration from the start of negotiations until the FTA is signed; "Negotiation-Implementation" refers to the duration from the start of negotiations until the FTA is implemented; "Signing-Implementation" refers to the duration from the signing of the FTA until the FTA is implemented; "Proposal-Implementation" refers to the duration from the first official proposal to form an FTA until the agreement is implemented; own calculations. 
Table 2: Duration between: start - end of negotiations; Log-logistic (frailty) models in AFT form

\begin{tabular}{|c|c|c|c|}
\hline & $(1)$ & (2) & (3) \\
\hline \multirow[t]{2}{*}{ FTA activity } & -0.00 & 0.00 & 0.00 \\
\hline & {$[0.003]$} & {$[0.002]$} & {$[0.006]$} \\
\hline \multirow[t]{2}{*}{ Trade openness } & -0.01 & -0.02 & $-0.06^{*}$ \\
\hline & {$[0.024]$} & {$[0.010]$} & {$[0.035]$} \\
\hline \multirow{2}{*}{ BTA } & $-0.69 * * *$ & $-0.68 * * *$ & $-0.48 * * *$ \\
\hline & [0.132] & [0.132] & [0.180] \\
\hline \multirow[t]{2}{*}{ WTO members } & $0.20 * *$ & -0.02 & 0.13 \\
\hline & {$[0.091]$} & {$[0.046]$} & [0.109] \\
\hline \multirow[t]{2}{*}{ Distance } & $0.31 * * *$ & $0.30 * * *$ & $0.25 * * *$ \\
\hline & {$[0.037]$} & {$[0.031]$} & [0.043] \\
\hline \multirow[t]{2}{*}{ Border } & $0.35 * * *$ & $0.24 * * *$ & $0.27^{* *}$ \\
\hline & {$[0.115]$} & {$[0.085]$} & [0.128] \\
\hline \multirow[t]{2}{*}{ Language } & 0.03 & 0.01 & -0.01 \\
\hline & {$[0.067]$} & {$[0.037]$} & {$[0.088]$} \\
\hline \multirow[t]{2}{*}{ GDP-per cap. } & 0.01 & -0.01 & 0.02 \\
\hline & {$[0.026]$} & {$[0.018]$} & {$[0.036]$} \\
\hline \multirow[t]{2}{*}{ GDP-per cap. (diff.) } & 0.00 & -0.00 & -0.01 \\
\hline & {$[0.021]$} & {$[0.013]$} & {$[0.028]$} \\
\hline \multirow[t]{2}{*}{ Democracy (sum) } & $-0.02 * *$ & --- & $-0.04 * * *$ \\
\hline & {$[0.008]$} & --- & [0.014] \\
\hline \multirow[t]{2}{*}{ Democracy (difference) } & 0.01 & --- & -0.01 \\
\hline & {$[0.008]$} & --- & {$[0.014]$} \\
\hline \multirow[t]{2}{*}{ PolConstr. (sum) } & --- & 0.02 & $0.23 * *$ \\
\hline & --- & {$[0.045]$} & [0.110] \\
\hline \multirow[t]{2}{*}{ PolConstr. (diff.) } & --- & -0.01 & -0.03 \\
\hline & --- & {$[0.011]$} & {$[0.027]$} \\
\hline \multirow[t]{2}{*}{ Avg. Tariff Level } & 0.01 & $0.01 *$ & 0.01 \\
\hline & {$[0.007]$} & {$[0.003]$} & [0.009] \\
\hline \multirow[t]{2}{*}{ EU } & $0.77 * * *$ & $0.67 * * *$ & $0.78 * * *$ \\
\hline & {$[0.078]$} & {$[0.053]$} & [0.108] \\
\hline \multirow[t]{2}{*}{ Constant } & $3.80 * * *$ & $4.06 * * *$ & $5.00 * * *$ \\
\hline & [0.452] & [0.320] & [0.588] \\
\hline \multirow[t]{2}{*}{ Ln_gamma } & $-1.39 * * *$ & $-1.61 * * *$ & $-1.33 * * *$ \\
\hline & [0.043] & [0.039] & [0.056] \\
\hline \multirow[t]{2}{*}{ Theta } & $10.85^{* * *}$ & $64.36 * * *$ & $9.46 * * *$ \\
\hline & {$[2.280]$} & [22.061] & [2.343] \\
\hline FTAs & 128 & 92 & 90 \\
\hline Observations & 1861 & 1989 & 1104 \\
\hline
\end{tabular}

Notes: "FTA activity" denotes the sum of a country-pairs' enforced agreements in any respective period; "Trade openness" is defined as the product of a country-pairs' exports/GDP; "BTA" denotes bilateral trade agreements; "WTO members" refers to a country-pair as being mutual members of the WTO; "Distance" denotes the bilateral great-circle distance between countries; "Border" refers to contiguity; "Language" denotes a common official language; "GDP-per cap." is calculated as the product of the per-capita income levels (in Logs); "GDP-per cap. (diff.)" is calculated as the difference in per-capita income levels (in Logs); "Democracy (sum)" and "Democracy (difference)" refer to the respective sum and difference in the polity2 index; "PolConstr. (sum)" and "PolConstr. (difference)" refer to the respective sum and difference in the Political Constraints index. "Avg. Tariff Level" denotes the average effectively applied import tariff between any country-pair in the FTA; "EU" signals that at a member country of the European Union is involved in the process. "FTAs" denotes the number FTAs in the regression for which data on the respective events were available. Note that the number of observations (countrypairs) and FTAs does not necessarily have to be proportional, as the data for the explanatory variables may be available for fewer FTAs (e.g. the political constraints index is only available until 2007) but at the same time for those which have the most observations, either via the number of country-pairs or the number of years for the duration.

$p<0.1,{ }^{* *} p<0.05,{ }^{* * *} p<0.01$, standard errors in parentheses 
Table 3: Duration between: signature - implementation; Log-logistic (frailty) models in AFT form

\begin{tabular}{|c|c|c|c|}
\hline & (1) & (2) & (3) \\
\hline \multirow[t]{2}{*}{ FTA activity } & $-0.01 * * *$ & $-0.05 * * *$ & $-0.04 * * *$ \\
\hline & {$[0.005]$} & {$[0.015]$} & {$[0.015]$} \\
\hline \multirow[t]{2}{*}{ Trade openness } & $-0.14 * * *$ & 0.07 & $-0.11^{*}$ \\
\hline & [0.039] & {$[0.064]$} & [0.063] \\
\hline \multirow[t]{2}{*}{ BTA } & 0.14 & 0.04 & -0.22 \\
\hline & [0.168] & [0.239] & [0.215] \\
\hline \multirow[t]{2}{*}{ WTO members } & $-0.65 * * *$ & -0.19 & $-0.33 * *$ \\
\hline & {$[0.142]$} & [0.165] & {$[0.151]$} \\
\hline \multirow[t]{2}{*}{ Distance } & $-0.49 * * *$ & 0.05 & -0.04 \\
\hline & {$[0.055]$} & [0.077] & {$[0.073]$} \\
\hline \multirow[t]{2}{*}{ Border } & -0.19 & $0.38 * *$ & 0.26 \\
\hline & {$[0.160]$} & [0.189] & [0.169] \\
\hline \multirow[t]{2}{*}{ Language } & $-0.17^{*}$ & $-0.57 * * *$ & -0.20 \\
\hline & [0.092] & {$[0.138]$} & {$[0.142]$} \\
\hline \multirow[t]{2}{*}{ GDP-per cap. } & -0.03 & $-0.13 * * *$ & $-0.14 * * *$ \\
\hline & [0.033] & {$[0.047]$} & [0.050] \\
\hline \multirow[t]{2}{*}{ GDP-per cap. (diff.) } & $0.07 * *$ & 0.01 & 0.00 \\
\hline & {$[0.032]$} & {$[0.057]$} & [0.053] \\
\hline \multirow[t]{2}{*}{ Democracy (sum) } & $0.14 * * *$ & --- & $0.13 * * *$ \\
\hline & {$[0.009]$} & --- & {$[0.014]$} \\
\hline \multirow[t]{2}{*}{ Democracy (difference) } & $0.20 * * *$ & --- & $0.18 * * *$ \\
\hline & {$[0.012]$} & --- & {$[0.017]$} \\
\hline \multirow[t]{2}{*}{ PolConstr. (sum) } & --- & $0.91 * * *$ & $0.39 * * *$ \\
\hline & --- & {$[0.171]$} & {$[0.143]$} \\
\hline \multirow[t]{2}{*}{ PolConstr. (diff.) } & --- & 0.06 & -0.02 \\
\hline & --- & {$[0.046]$} & {$[0.044]$} \\
\hline \multirow[t]{2}{*}{ Avg. Tariff Level } & $-0.04 * * *$ & $-0.09 * * *$ & $-0.04 * * *$ \\
\hline & [0.007] & [0.012] & [0.009] \\
\hline \multirow[t]{2}{*}{ EU } & $-0.44 * * *$ & $1.04 * * *$ & $0.59 * * *$ \\
\hline & [0.139] & [0.182] & [0.169] \\
\hline \multirow[t]{2}{*}{ Constant } & $7.83 * * *$ & $6.22 * * *$ & $4.68 * * *$ \\
\hline & [0.579] & [0.887] & [0.792] \\
\hline \multirow[t]{2}{*}{ Ln_gamma } & $-0.92 * * *$ & $-0.74 * * *$ & $-0.90 * * *$ \\
\hline & {$[0.046]$} & {$[0.052]$} & {$[0.058]$} \\
\hline \multirow[t]{2}{*}{ Theta } & $3.20 * * *$ & $3.50 * * *$ & $2.29 * * *$ \\
\hline & {$[0.608]$} & {$[0.779]$} & {$[0.537]$} \\
\hline FTAs & 133 & 99 & 99 \\
\hline Observations & 1265 & 961 & 859 \\
\hline
\end{tabular}

Notes: "FTA activity" denotes the sum of a country-pairs' enforced agreements in any respective period; "Trade openness" is defined as the product of a country-pairs" exports/GDP; "BTA" denotes bilateral trade agreements; "WTO members" refers to a country-pair as being mutual members of the WTO; "Distance" denotes the bilateral great-circle distance between countries; "Border" refers to contiguity; "Language" denotes a common official language; "GDP-per cap." is calculated as the product of the per-capita income levels (in Logs); "GDP-per cap. (diff.)" is calculated as the difference in per-capita income levels (in Logs); "Democracy (sum)" and "Democracy (difference)" refer to the respective sum and difference in the polity2 index; "PolConstr. (sum)" and "PolConstr. (difference)" refer to the respective sum and difference in the Political Constraints index. "Avg. Tariff Level" denotes the average effectively applied import tariff between any country-pair in the FTA; "EU" signals that at a member country of the European Union is involved in the process. "FTAs" denotes the number FTAs in the regression for which data on the respective events were available. Note that the number of observations (countrypairs) and FTAs does not necessarily have to be proportional, as the data for the explanatory variables may be available for fewer FTAs (e.g. the political constraints index is only available until 2007) but at the same time for those which have the most observations, either via the number of country-pairs or the number of years for the duration.

${ }^{*} p<0.1,{ }^{* *} p<0.05,{ }^{* * *} p<0.01$, standard errors in parentheses 
Table 4: Duration between: negotiation start - implementation; Log-logistic (frailty) models in AFT form

\begin{tabular}{|c|c|c|c|}
\hline & (1) & (2) & (3) \\
\hline \multirow[t]{2}{*}{ FTA activity } & 0.00 & -0.01 & 0.01 \\
\hline & {$[0.002]$} & [0.007] & [0.007] \\
\hline \multirow[t]{2}{*}{ Trade openness } & 0.00 & $-0.07 * * *$ & $-0.13 * * *$ \\
\hline & [0.013] & {$[0.025]$} & {$[0.024]$} \\
\hline \multirow[t]{2}{*}{ BTA } & $-0.43 * * *$ & -0.01 & -0.04 \\
\hline & {$[0.082]$} & {$[0.108]$} & {$[0.110]$} \\
\hline \multirow[t]{2}{*}{ WTO members } & 0.08 & $-0.29 * * *$ & $-0.41 * * *$ \\
\hline & {$[0.061]$} & {$[0.084]$} & [0.077] \\
\hline \multirow[t]{2}{*}{ Distance } & $0.09 * * *$ & 0.02 & 0.02 \\
\hline & {$[0.025]$} & [0.031] & {$[0.031]$} \\
\hline \multirow[t]{2}{*}{ Border } & $0.11^{*}$ & -0.04 & 0.01 \\
\hline & {$[0.066]$} & {$[0.071]$} & [0.079] \\
\hline \multirow[t]{2}{*}{ Language } & 0.01 & -0.00 & 0.06 \\
\hline & {$[0.036]$} & {$[0.058]$} & {$[0.062]$} \\
\hline \multirow[t]{2}{*}{ GDP-per cap. } & $-0.05 * * *$ & $-0.06 * * *$ & $-0.08 * * *$ \\
\hline & {$[0.014]$} & {$[0.022]$} & {$[0.024]$} \\
\hline \multirow[t]{2}{*}{ GDP-per cap. (diff.) } & 0.00 & 0.01 & 0.02 \\
\hline & {$[0.012]$} & [0.024] & [0.027] \\
\hline \multirow[t]{2}{*}{ Democracy (sum) } & $0.02 * * *$ & --- & -0.01 \\
\hline & {$[0.003]$} & --- & {$[0.005]$} \\
\hline \multirow[t]{2}{*}{ Democracy (difference) } & $0.04 * * *$ & --- & $0.05^{* * *}$ \\
\hline & [0.005] & --- & {$[0.008]$} \\
\hline \multirow[t]{2}{*}{ PolConstr. (sum) } & --- & $0.45^{* * *}$ & $0.63^{* * *}$ \\
\hline & --- & [0.057] & {$[0.066]$} \\
\hline \multirow[t]{2}{*}{ PolConstr. (diff.) } & --- & -0.01 & $-0.04 * *$ \\
\hline & --- & {$[0.017]$} & {$[0.018]$} \\
\hline \multirow[t]{2}{*}{ Avg. Tariff Level } & $-0.02 * * *$ & $-0.04 * * *$ & $-0.04 * * *$ \\
\hline & {$[0.002]$} & {$[0.004]$} & [0.004] \\
\hline \multirow[t]{2}{*}{ EU } & $0.47 * * *$ & $0.42 * * *$ & $0.38 * * *$ \\
\hline & {$[0.056]$} & {$[0.071]$} & {$[0.080]$} \\
\hline \multirow[t]{2}{*}{ Constant } & $5.85^{* * *}$ & $7.32 * * *$ & $7.18^{* * *}$ \\
\hline & {$[0.260]$} & {$[0.345]$} & {$[0.342]$} \\
\hline \multirow[t]{2}{*}{ Ln_gamma } & $-1.85^{* * *}$ & $-1.81 * * *$ & $-1.98 * * *$ \\
\hline & [0.044] & [0.065] & [0.078] \\
\hline \multirow[t]{2}{*}{ Theta } & $4.89 * * *$ & $6.94^{* * *}$ & $4.81 * * *$ \\
\hline & [1.028] & [1.499] & {$[0.979]$} \\
\hline FTAs & 132 & 95 & 95 \\
\hline Observations & 3073 & 2824 & 1816 \\
\hline
\end{tabular}

Notes: "FTA activity" denotes the sum of a country-pairs' enforced agreements in any respective period; "Trade openness" is defined as the product of a country-pairs' exports/GDP; "BTA" denotes bilateral trade agreements; "WTO members" refers to a country-pair as being mutual members of the WTO; "Distance" denotes the bilateral great-circle distance between countries; "Border" refers to contiguity; "Language" denotes a common official language; "GDP-per cap." is calculated as the product of the per-capita income levels (in Logs); "GDP-per cap. (diff.)" is calculated as the difference in per-capita income levels (in Logs); "Democracy (sum)" and "Democracy (difference)" refer to the respective sum and difference in the polity2 index; "PolConstr. (sum)" and "PolConstr. (difference)" refer to the respective sum and difference in the Political Constraints index. "Avg. Tariff Level" denotes the average effectively applied import tariff between any country-pair in the FTA; "EU" signals that at a member country of the European Union is involved in the process. "FTAs" denotes the number FTAs in the regression for which data on the respective events were available. Note that the number of observations (countrypairs) and FTAs does not necessarily have to be proportional, as the data for the explanatory variables may be available for fewer FTAs (e.g. the political constraints index is only available until 2007) but at the same time for those which have the most observations, either via the number of country-pairs or the number of years for the duration.

${ }^{*} p<0.1,{ }^{* *} p<0.05,{ }^{* * *} p<0.01$, standard errors in parentheses 


\section{Appendix}

Table A1: Duration between: proposal - implementation; Log-logistic (frailty) models in AFT form

\begin{tabular}{|c|c|c|c|}
\hline & (1) & $(2)$ & (3) \\
\hline \multirow[t]{2}{*}{ FTA activity } & -0.00 & $-0.02 * * *$ & $-0.01^{*}$ \\
\hline & [0.003] & {$[0.006]$} & {$[0.006]$} \\
\hline \multirow[t]{2}{*}{ Trade openness } & $-0.03^{* *}$ & $-0.09 * * *$ & $-0.11 * * *$ \\
\hline & {$[0.016]$} & {$[0.020]$} & {$[0.024]$} \\
\hline \multirow[t]{2}{*}{ BTA } & $-0.33 * * *$ & 0.00 & -0.09 \\
\hline & {$[0.074]$} & [0.098] & [0.099] \\
\hline \multirow[t]{2}{*}{ WTO members } & $0.22 * * *$ & 0.09 & 0.03 \\
\hline & {$[0.072]$} & {$[0.093]$} & {$[0.126]$} \\
\hline \multirow[t]{2}{*}{ Distance } & $0.12 * * *$ & $0.12 * * *$ & $0.12 * * *$ \\
\hline & {$[0.022]$} & {$[0.032]$} & {$[0.031]$} \\
\hline \multirow[t]{2}{*}{ Border } & 0.08 & 0.00 & -0.03 \\
\hline & {$[0.058]$} & {$[0.069]$} & [0.089] \\
\hline \multirow[t]{2}{*}{ Language } & 0.05 & 0.03 & $0.11^{*}$ \\
\hline & {$[0.036]$} & {$[0.049]$} & {$[0.064]$} \\
\hline \multirow[t]{2}{*}{ GDP-per cap. } & $-0.07 * * *$ & $-0.05^{* *}$ & $-0.05^{* *}$ \\
\hline & {$[0.014]$} & {$[0.020]$} & {$[0.021]$} \\
\hline \multirow[t]{2}{*}{ GDP-per cap. (diff.) } & 0.02 & 0.01 & 0.02 \\
\hline & {$[0.012]$} & {$[0.019]$} & {$[0.018]$} \\
\hline \multirow[t]{2}{*}{ Democracy (sum) } & $0.02 * * *$ & --- & 0.00 \\
\hline & {$[0.003]$} & --- & {$[0.005]$} \\
\hline \multirow[t]{2}{*}{ Democracy (difference) } & $0.03 * * *$ & --- & $0.03^{* * *}$ \\
\hline & {$[0.004]$} & --- & {$[0.006]$} \\
\hline \multirow[t]{2}{*}{ PolConstr. (sum) } & --- & $0.33 * * *$ & $0.40 * * *$ \\
\hline & --- & [0.043] & {$[0.058]$} \\
\hline \multirow[t]{2}{*}{ PolConstr. (diff.) } & --- & -0.01 & $-0.05^{* *}$ \\
\hline & --- & [0.016] & [0.019] \\
\hline \multirow[t]{2}{*}{ Avg. Tariff Level } & $-0.02 * * *$ & $-0.03 * * *$ & $-0.03 * * *$ \\
\hline & [0.002] & [0.003] & [0.004] \\
\hline \multirow[t]{2}{*}{ EU } & $0.46 * * *$ & $0.77 * * *$ & $0.72 * * *$ \\
\hline & {$[0.057]$} & {$[0.079]$} & {$[0.082]$} \\
\hline \multirow[t]{2}{*}{ Constant } & $5.75^{* * *}$ & $6.53^{* * *}$ & $6.36 * * *$ \\
\hline & [0.255] & {$[0.347]$} & [0.345] \\
\hline \multirow[t]{2}{*}{ Ln_gamma } & $-2.04 * * *$ & $-2.05 * * *$ & $-2.17 * * *$ \\
\hline & [0.054] & {$[0.070]$} & [0.083] \\
\hline \multirow[t]{2}{*}{ Theta } & $3.86^{* * *}$ & $6.10^{* * *}$ & $4.74^{* * *}$ \\
\hline & {$[0.791]$} & [1.351] & [1.009] \\
\hline FTAs & 114 & 98 & 97 \\
\hline Observations & 3282 & 2491 & 2157 \\
\hline
\end{tabular}

Notes: "FTA activity" denotes the sum of a country-pairs' enforced agreements in any respective period; "Trade openness" is defined as the product of a country-pairs' exports/GDP; "BTA" denotes bilateral trade agreements; "WTO members" refers to a country-pair as being mutual members of the WTO; "Distance" denotes the bilateral great-circle distance between countries; "Border" refers to contiguity; "Language" denotes a common official language; "GDP-per cap." is calculated as the product of the per-capita income levels (in Logs); "GDP-per cap. (diff.)" is calculated as the difference in per-capita income levels (in Logs); "Democracy (sum)" and "Democracy (difference)" refer to the respective sum and difference in the polity2 index; "PolConstr. (sum)" and "PolConstr. (difference)" refer to the respective sum and difference in the Political Constraints index. "Avg. Tariff Level" denotes the average effectively applied import tariff between any country-pair in the FTA; "EU" signals that at a member country of the European Union is involved in the process. "FTAs" denotes the number FTAs in the regression for which data on the respective events were available. Note that the number of observations (countrypairs) and FTAs does not necessarily have to be proportional, as the data for the explanatory variables may be available for fewer FTAs (e.g. the political constraints index is only available until 2007) but at the same time for those which have the most observations, either via the number of country-pairs or the number of years for the duration. ${ }^{*} p<0.1,{ }^{* *} p<0.05,{ }^{* * *} p<0.01$, standard errors in parentheses 


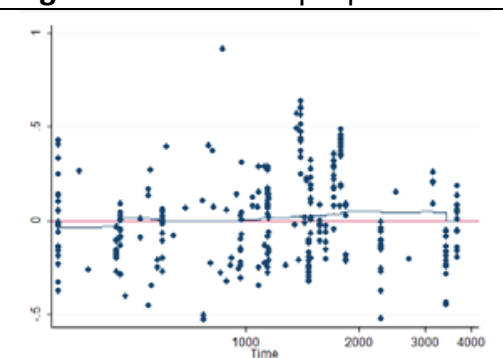

"FTA activity"

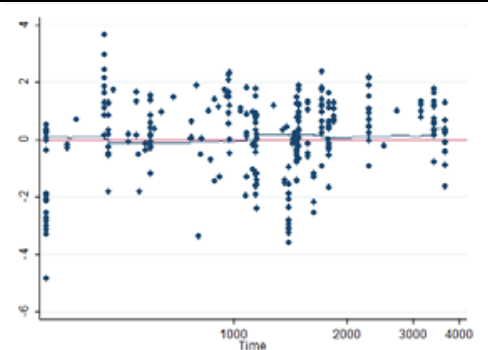

“Trade openness”

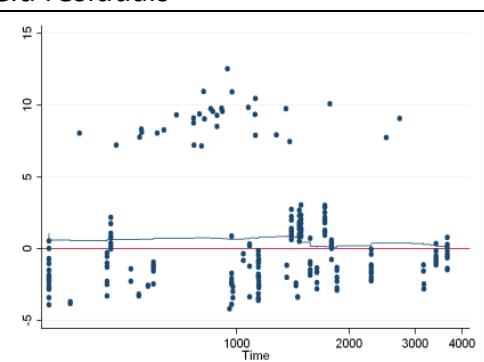

"Bilateral FTA"

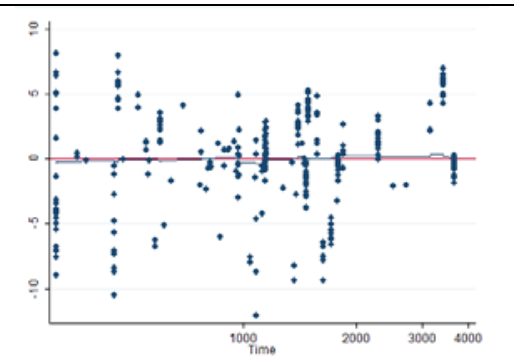

"WTO members"

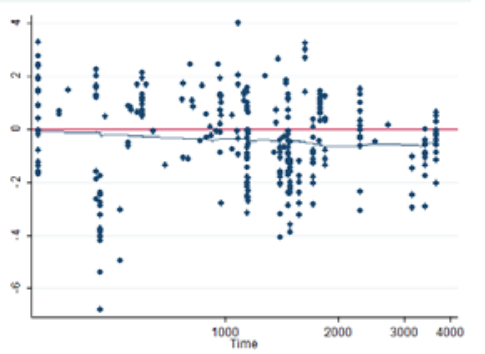

"Distance"
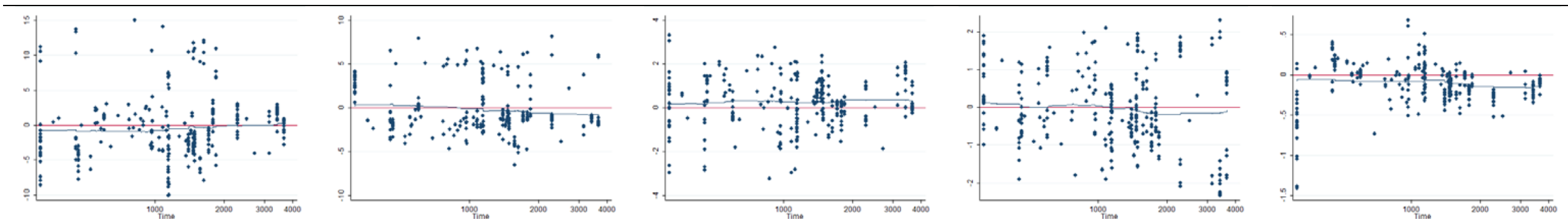

"Contiguity"

"Language"

“GDP-pc”

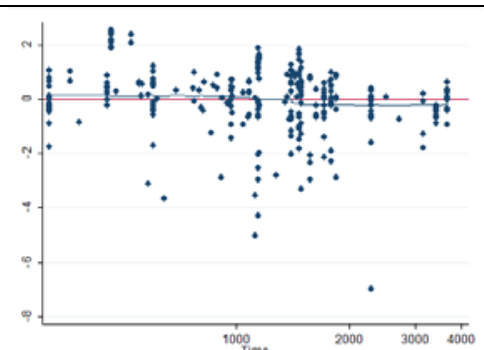

"Pol. Constraints (diff.)"

“GDP-pc (diff.)”

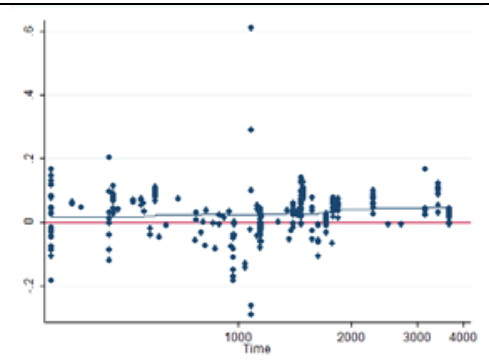

"Tariffs"
“Democracy”

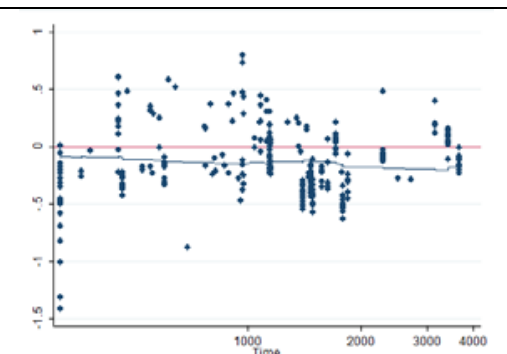

“Democracy (diff.)”

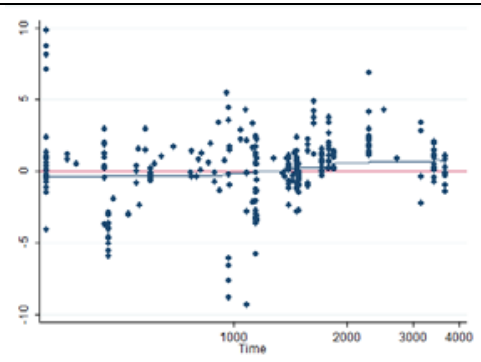

"Pol. constraints"

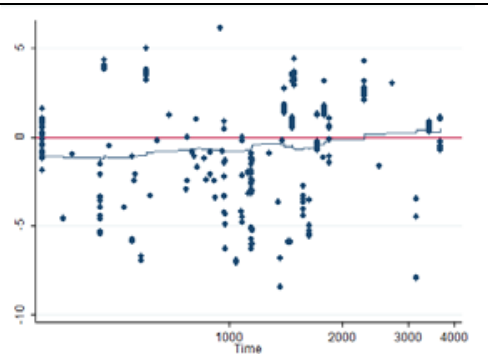

"EU members"

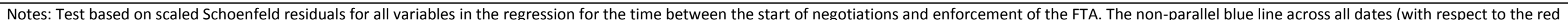
line) is an indication of non-proportionality. 
Table A2: FTAs included in the dataset

\begin{tabular}{|c|c|c|c|c|c|c|}
\hline FTA & Date - FTA proposed & Date -Start Negotiations & Date - End Negotiations & \# of rounds & Date - FTA signed & Date - FTA implemented \\
\hline ASEAN - Australia - New Zealand & Nov 01, 2004 & Mar 01, 2005 & Aug 28,2008 & 16 & Feb 27, 2009 & Jan 01,2010 \\
\hline ASEAN - China & Nov 23, 2000 & Nov 04,2002 & Oct 26,2004 & --- & Nov 29, 2004 & Jul 01, 2005 \\
\hline ASEAN - India & --- & Mar 07, 2004 & --- & --- & Aug 13, 2009 & Jan 01, 2010 \\
\hline ASEAN - Japan & Jan 01, 2002 & Apr 14, 2005 & Nov 12,2007 & 11 & Apr 15, 2008 & Dec 01, 2008 \\
\hline ASEAN - Korea, Republic of & Oct 08,2003 & Nov 30, 2004 & --- & 25 & Aug 24,2006 & Jun 01, 2007 \\
\hline ASEAN Free Trade Area (AFTA) & Jun 24, 1991 & Oct 08, 1991 & --- & --- & $\operatorname{Jan} 28,1992$ & Jan 01, 1993 \\
\hline Armenia - Kazakhstan & --- & --- & --- & --- & Sep 02, 1999 & Dec 25, 2001 \\
\hline Armenia - Moldova & --- & --- & --- & --- & Dec 24, 1993 & Dec 21, 1995 \\
\hline Armenia - Russian Federation & ---- & --- & --- & --- & Sep 30, 1992 & Mar 25, 1993 \\
\hline Armenia - Turkmenistan & --- & --- & --- & --- & Oct 03,1995 & Jul 07, 1996 \\
\hline Armenia - Ukraine & --- & --- & --- & --- & Oct 07,1994 & Dec 18, 1996 \\
\hline Asia Pacific Trade Agreement (APTA) & --- & Feb 01, 1972 & Jul 01, 1975 & 3 & May 28,1976 & May 29, 1976 \\
\hline Australia - Chile & Nov 10,2006 & Jul 18, 2007 & May 27,2008 & 4 & Jul 30, 2008 & Mar 05, 2009 \\
\hline Australia - China & --- & May 23,2005 & -- & --- & --- & --- \\
\hline Australia - Gulf Cooperation Council (GCC) & Jun 01, 2006 & Jul 30, 2007 & --- & --- & $-\ldots$ & --- \\
\hline Australia - Malaysia & --- & May 19, 2005 & --- & --- & May 22, 2012 & --- \\
\hline Australia - New Zealand (ANZCERTA) & Mar 01, 1980 & --- & --- & --- & Dec 14, 1982 & Jan 01, 1983 \\
\hline Australia - Papua New Guinea (PATCRA) & --- & --- & --- & --- & Nov 06, 1976 & Feb 01, 1977 \\
\hline $\begin{array}{l}\text { Bay of Bengal Initiative on Multi-Sectoral } \\
\text { Technical and Economic Cooperation } \\
\text { (BIMSTEC) }\end{array}$ & --- & Sep 07, 2004 & --- & --- & --- & --- \\
\hline Brunei Darussalam - Japan & $\operatorname{Jan} 14,2003$ & Jun 27,2006 & --- & --- & Jun 18,2007 & Jul 31, 2008 \\
\hline Canada - CARICOM & Jul 19, 2007 & Nov 09, 2009 & --- & --- & --- & --- \\
\hline Canada - Chile & Dec 29, 1995 & Jan 01, 1996 & Nov 14, 1996 & 9 & Nov 18,1996 & Jul 05, 1997 \\
\hline Canada - Colombia & Aug 01, 2002 & Jun 07,2007 & Jun 07,2008 & 5 & Nov 21,2008 & Aug 15,2011 \\
\hline Canada - Costa Rica & $\operatorname{Jan} 31,2000$ & Jun 30,2000 & Apr 01, 2001 & 7 & Apr 23, 2001 & Nov 01, 2002 \\
\hline Canada - Dominican Republic & --- & Jun 07,2007 & --- & --- & --- & --- \\
\hline $\begin{array}{l}\text { Canada - El Salvador - Guatemala - } \\
\text { Honduras - Nicaragua (Honduras out) }\end{array}$ & --- & Nov 21, 2001 & Aug 12, 2011 & --- & --- & --- \\
\hline Canada - Honduras & --- & Dec 06, 2010 & --- & --- & --- & --- \\
\hline Canada - Israel & Mar 30, 1992 & Nov 23, 1994 & --- & --- & Jul 31, 1996 & Jan 01, 1997 \\
\hline Canada - Jordan & --- & Feb 20, 2008 & Aug 25,2008 & --- & Jun 28,2009 & --- \\
\hline Canada - Peru & Aug 07,2002 & Jun 07,2007 & $\operatorname{Jan} 26,2008$ & 3 & May 29, 2008 & Aug 01, 2009 \\
\hline Canada - Singapore & --- & Oct 21, 2001 & --- & --- & --- & --- \\
\hline Canada - Ukraine & Oct 31, 2009 & May 17, 2010 & --- & --- & --- & --- \\
\hline $\begin{array}{l}\text { Caribbean Community and Common } \\
\text { Market (CARICOM) }\end{array}$ & --- & --- & --- & --- & Apr 13, 1973 & Aug 01, 1973 \\
\hline $\begin{array}{l}\text { Central European Free Trade Agreement } \\
\text { (CEFTA) } 2006 \text { enlargement }\end{array}$ & Sep 16, 2002 & Apr 06, 2003 & --- & --- & Dec 19, 2006 & Jul 26, 2007 \\
\hline Chile - China & Jun 01,2002 & $\operatorname{Jan} 25,2005$ & Nov 07,2005 & 5 & Nov 18,2005 & Oct 01, 2006 \\
\hline Chile - Colombia & Jul 27, 2006 & Oct 09, 2006 & Oct 30,2006 & 2 & Nov 27, 2006 & May 08, 2009 \\
\hline
\end{tabular}




\begin{tabular}{|c|c|c|c|c|c|c|}
\hline Chile - Costa Rica (Chile - Central America) & --- & Aug 17,1998 & Sep 01, 1999 & 5 & Nov 18,1999 & Feb 15, 2002 \\
\hline Chile - El Salvador (Chile - Central America) & --- & Aug 17,1998 & Sep 01, 1999 & 5 & Nov 20,2000 & Jun 03, 2002 \\
\hline Chile - India & Jun 30, 2004 & Apr 04, 2005 & Nov 23, 2005 & 4 & Mar 08, 2006 & Aug 17, 2007 \\
\hline Chile - Japan & Nov 17,2004 & Feb 23, 2006 & Sep 04, 2006 & 4 & Mar 27, 2007 & Sep 03, 2007 \\
\hline Chile - Mexico & $\begin{array}{ll}--- \\
\end{array}$ & --- & --- & --- & Apr 17, 1998 & Aug 01, 1999 \\
\hline China - Hong Kong, China & Dec 13, 2001 & --- & Jun 13,2003 & --- & Jun 29,2003 & Jan 01, 2004 \\
\hline China - New Zealand & Apr 14, 2004 & Dec 01, 2004 & Dec 01, 2007 & 15 & Apr 07, 2008 & Oct 01,2008 \\
\hline China - Norway & --- & Sep 18,2008 & --- & --- & --- & --- \\
\hline China - Singapore & Oct 29, 2003 & Aug 25, 2006 & Sep 03, 2008 & 8 & Oct 23, 2008 & Jan 01, 2009 \\
\hline Colombia - Mexico (G-3) & Apr 09, 1990 & --- & --- & --- & Jun 13, 1994 & Jan 01, 1995 \\
\hline Common Economic Zone (CEZ) & Feb 25, 2003 & --- & --- & --- & Sep 19, 2003 & May 20,2004 \\
\hline $\begin{array}{l}\text { Common Market for Eastern and Southern } \\
\text { Africa (COMESA) }\end{array}$ & --- & --- & Jan 20, 1993 & --- & Nov 05, 1993 & Dec 08, 1994 \\
\hline Costa Rica - Mexico & $\operatorname{Jan} 01,1991$ & Apr 01, 1993 & --- & --- & Apr 05, 1994 & Jan 01, 1995 \\
\hline Costa Rica - Peru & --- & Nov 08,2010 & May 06, 2011 & --- & May 26, 2011 & --- \\
\hline Costa Rica - Singapore & Dec 04, 2008 & Apr 20, 2009 & $\operatorname{Jan} 29,2010$ & --- & Apr 06, 2010 & --- \\
\hline $\begin{array}{l}\text { Dominican Republic - Central America - } \\
\text { United States Free Trade Agreement } \\
\text { (CAFTA-DR) W/O DomRep }\end{array}$ & Jan 16, 2002 & Jan 08, 2003 & Jan 25, 2004 & 9 & Aug 05, 2004 & Mar 01, 2006 \\
\hline $\begin{array}{l}\text { Dominican Republic - Central America - } \\
\text { United States Free Trade Agreement } \\
\text { (CAFTA-DR) w/ DomRep }\end{array}$ & Jan 16, 2002 & Jan 12, 2004 & Mar 15, 2004 & 10 & Aug 06, 2004 & Mar 01, 2007 \\
\hline EC-Albania & May 26, 1999 & $\operatorname{Jan} 31,2003$ & Feb 28, 2006 & --- & Jun 12, 2006 & Dec 01, 2006 \\
\hline EC - Algeria & --- & Dec 14, 2000 & Dec 19, 2001 & --- & Apr 12, 2002 & Sep 01, 2005 \\
\hline EC - Andorra & --- & Apr 13, 1989 & --- & --- & Mar 15, 1990 & Jul 01, 1991 \\
\hline EC - Bosnia and Herzegovina & May 26, 1999 & Nov 25, 2005 & Dec 01, 2006 & --- & Jun 16,2008 & Jul 01, 2008 \\
\hline EC - CARIFORUM States EPA & $\begin{array}{c}-- \\
-\end{array}$ & Apr 01, 2004 & Dec 17, 2007 & 14 & Oct 15, 2008 & Nov 01,2008 \\
\hline EC - Cameroon & --- & Sep 27,2002 & --- & --- & Jan 15, 2009 & Oct 01, 2009 \\
\hline EC - Chile & Jul 22, 1998 & Apr 01, 2000 & Apr 26, 2002 & 10 & Nov 18,2002 & Mar 01, 2005 \\
\hline EC - Croatia & May 26, 1999 & Nov 24,2000 & May 14,2001 & --- & Oct 29, 2001 & Mar 01, 2002 \\
\hline EC - Côte d'Ivoire & Jun 12,2002 & Sep 27, 2002 & Dec 07, 2007 & --- & Nov 26, 2008 & $\operatorname{Jan} 01,2009$ \\
\hline EC - Egypt & Nov 04, 1994 & $\operatorname{Jan} 26,1995$ & Jan 26, 2001 & --- & Jun 25,2001 & Jun 01, 2004 \\
\hline EC - Faroe Islands & --- & --- & --- & --- & Dec 06, 1996 & Jan 01, 1997 \\
\hline $\begin{array}{l}\text { EC - Former Yugoslav Republic of } \\
\text { Macedonia }\end{array}$ & May 26, 1999 & Mar 07, 2000 & Nov 24, 2000 & --- & Apr 09, 2001 & Apr 01, 2004 \\
\hline EC - Israel & Dec 06, 1992 & $-{ }_{---}$ & Jul 19, 1995 & --- & Nov 20, 1995 & Jun 01,2000 \\
\hline EC - Jordan & Jun 23, 1995 & --- & Apr 16, 1997 & --- & Nov 24, 1997 & May 01,2002 \\
\hline EC - Lebanon & Nov 28,1995 & Mar 29, 1996 & $\operatorname{Jan} 10,2002$ & --- & Jun 17,2002 & Apr 01, 2006 \\
\hline EC - Mexico & Oct 24, 1995 & Nov 09, 1998 & Nov 24, 1999 & 2 & Mar 23, 2000 & Jul 01, 2000 \\
\hline EC - Montenegro & May 23, 2006 & Sep 26, 2006 & Dec 01, 2006 & --- & Oct 16, 2007 & May 01, 2010 \\
\hline EC - Morocco & --- & Nov 24, 1993 & Nov 16,1995 & --- & Feb 26, 1996 & Mar 01, 2000 \\
\hline EC - Palestinian Authority & Jul 18, 1996 & --- & Dec 11, 1996 & --- & Feb 24, 1997 & Jul 01, 1997 \\
\hline
\end{tabular}




\begin{tabular}{|c|c|c|c|c|c|c|}
\hline $\begin{array}{l}\text { EC - South Africa Trade, Development and } \\
\text { Cooperation Agreement (TDCA) }\end{array}$ & Oct 10, 1994 & Jun 30, 1995 & Mar 25, 1999 & --- & Oct 11, 1999 & $\operatorname{Jan} 01,2004$ \\
\hline EC - Syria & --- & --- & --- & --- & $\operatorname{Jan} 18,1977$ & Jan 01, 1977 \\
\hline EC - Tunisia & Nov 24, 1993 & --- & Apr 21, 1995 & --- & Jul 17, 1995 & Mar 01, 1998 \\
\hline EFTA - Albania & --- & May 12, 2009 & Jun 26, 2009 & 2 & Dec 17, 2009 & Nov 01,2010 \\
\hline EFTA - Bosnia and Herzegovina & --- & Mar 28, 2011 & --- & --- & --- & --- \\
\hline EFTA - Canada & Dec 05, 1997 & Oct 09, 1998 & Jun 07,2007 & 10 & Jan 26, 2008 & Jul 01, 2009 \\
\hline EFTA - Chile & Nov 21,2000 & Dec 04, 2000 & Mar 25, 2003 & 6 & Jun 26, 2003 & Dec 01, 2004 \\
\hline EFTA - Colombia & Oct 05, 2006 & Jun 08, 2007 & Jun 12, 2008 & 5 & Nov 25, 2008 & Jul 01, 2011 \\
\hline EFTA - Croatia & Jun 19,2000 & Oct 26, 2000 & Feb 23, 2001 & 2 & Jun 21, 2001 & Apr 01, 2002 \\
\hline EFTA - Egypt & Dec 08, 1995 & Dec 02, 1998 & Oct 31, 2006 & 10 & $\operatorname{Jan} 27,2007$ & Aug 01, 2007 \\
\hline $\begin{array}{l}\text { EFTA - Former Yugoslav Republic of } \\
\text { Macedonia }\end{array}$ & --- & Jun 22, 1999 & May 12,2000 & 5 & Jun 19, 2000 & May 01, 2002 \\
\hline EFTA - GCC & May 23,2000 & Jun 20, 2006 & Apr 24, 2008 & --- & Jun 22,2009 & --- \\
\hline EFTA - Hong Kong, China & --- & $\operatorname{Jan} 18,2010$ & --- & --- & Jun 21, 2011 & --- \\
\hline EFTA - India & Dec 01, 2006 & Oct 06, 2008 & --- & --- & --- & --- \\
\hline EFTA - Indonesia & Nov 29,2005 & $\operatorname{Jan} 31,2011$ & --- & --- & --- & --- \\
\hline EFTA - Israel & --- & Jun 01, 1991 & Jul 16, 1992 & --- & Sep 17, 1992 & $\operatorname{Jan} 01,1993$ \\
\hline EFTA - Jordan & --- & Sep 22, 1998 & May 19,2000 & 3 & Jun 21, 2001 & Sep 01, 2002 \\
\hline EFTA - Korea, Republic of & Dec 10, 2004 & $\operatorname{Jan} 17,2005$ & Jul 08, 2005 & 4 & Dec 15, 2005 & Sep 01, 2006 \\
\hline EFTA - Lebanon & Dec 12, 2002 & Apr 08, 2003 & Mar 12, 2004 & 3 & Jun 24,2004 & Jan 01, 2007 \\
\hline EFTA - Mexico & Jun 05, 1999 & Jul 06, 2000 & Nov 03,2000 & 4 & Nov 27,2000 & Jul 01, 2001 \\
\hline EFTA - Montenegro & --- & Apr 01, 2011 & Jul 01, 2011 & --- & Nov 14, 2011 & --- \\
\hline EFTA - Morocco & Dec 08, 1995 & --- & --- & --- & Jun 19, 1997 & Dec 01, 1999 \\
\hline EFTA - Palestinian Authority & --- & $\operatorname{Jan} 22,1998$ & Oct 23, 1998 & 3 & Nov 30, 1998 & Jul 01, 1999 \\
\hline EFTA - Peru & --- & Jun 04, 2007 & Oct 31, 2008 & 5 & Jun 24,2010 & Jul 01, 2011 \\
\hline $\begin{array}{l}\text { EFTA - Russian Federation / Belarus / } \\
\text { Kazakhstan }\end{array}$ & --- & Jan 11, 2011 & --- & --- & --- & --- \\
\hline EFTA - SACU & Nov 06,2000 & May 19, 2003 & Aug 26,2005 & 7 & Jun 26, 2006 & May 01, 2008 \\
\hline EFTA - Serbia & --- & Apr 28, 2009 & Jun 12, 2009 & 2 & Dec 17, 2009 & Oct 01,2010 \\
\hline EFTA - Singapore & $\operatorname{Jan} 10,2001$ & Jul 02, 2001 & Nov 07,2001 & 3 & Jun 26,2002 & Jan 01, 2003 \\
\hline EFTA - Tunisia & Dec 08, 1995 & Oct 07,1996 & Apr 07, 2004 & 6 & Dec 17, 2004 & Jun 01, 2005 \\
\hline EFTA - Turkey & --- & --- & Oct 17, 1991 & --- & Dec 10, 1991 & Apr 01, 1992 \\
\hline EFTA accession of Iceland & --.- & $\operatorname{Jan} 24,1969$ & --- & --- & --- & Mar 01, 1970 \\
\hline EU - Canada & $\operatorname{Jan} 26,2007$ & May 06, 2009 & --- & --- & --- & --- \\
\hline EU - India & Sep 07, 2005 & Jun 28,2007 & --- & --- & --- & --- \\
\hline EU - Korea, Republic of & Dec 09, 2005 & May 07, 2007 & Oct 15, 2009 & 8 & Oct 06, 2010 & Jul 01, 2011 \\
\hline EU - Serbia & --- & Oct 10, 2005 & Sep 10, 2007 & 5 & Apr 29, 2008 & Feb 01, 2010 \\
\hline EU - Ukraine & $\operatorname{Jan} 18,2005$ & Feb 18,2008 & --- & --- & --- & --- \\
\hline East African Community (EAC) & Apr 29, 1997 & --- & --- & --- & Nov 30, 1999 & Jul 07, 2000 \\
\hline Economic Cooperation Organization (ECO) & --- & --- & --- & --- & Jun 19, 1990 & Feb 17, 1992 \\
\hline Egypt - Turkey & Oct 20, 1998 & --- & Mar 31, 2005 & 6 & Dec 27, 2005 & May 01, 2007 \\
\hline European Economic Area (EEA) & --- & Dec 23, 1989 & Oct 22,1991 & --- & May 02, 1992 & $\operatorname{Jan} 01,1994$ \\
\hline
\end{tabular}




\begin{tabular}{|c|c|c|c|c|c|c|}
\hline European Free Trade Association (EFTA) & --- & --- & --- & --- & $\operatorname{Jan} 04,1960$ & May 03, 1960 \\
\hline European Union - Papua New Guinea / Fiji & Jun 17,2002 & --- & Dec 03, 2007 & --- & Jul 30, 2009 & Dec 20, 2009 \\
\hline $\begin{array}{l}\text { Free Trade Agreement between members } \\
\text { of the Commonwealth of Independent } \\
\text { States (CIS) }\end{array}$ & Jul 19, 2010 & --- & --- & --- & Oct 18, 2011 & --- \\
\hline Georgia - Armenia & --- & --- & --- & --- & Aug 14, 1995 & Nov 11,1998 \\
\hline Georgia - Azerbaijan & --- & --- & --- & --- & Mar 08, 1996 & Jul 10, 1996 \\
\hline Georgia - Kazakhstan & --- & --- & --- & --- & Nov 11,1997 & Jul 16, 1999 \\
\hline Georgia - Russian Federation & --- & --- & --- & --- & Feb 03, 1994 & May 10,1994 \\
\hline Georgia - Turkmenistan & --- & --- & --- & --- & Mar 20, 1996 & Jan 01, 2000 \\
\hline Georgia - Ukraine & --- & --- & --- & --- & Jan 09, 1995 & Jun 04, 1996 \\
\hline $\begin{array}{l}\text { Global System of Trade Preferences among } \\
\text { Developing Countries (GSTP) }\end{array}$ & Aug 28, 1977 & May 01, 1986 & Apr 01, 1988 & 1 & Apr 13, 1988 & Apr 19, 1989 \\
\hline $\begin{array}{l}\text { Guatemala - the Separate Customs } \\
\text { Territory of Taiwan, Penghu, Kinmen and } \\
\text { Matsu }\end{array}$ & --- & Mar 01, 2005 & Jul 31, 2005 & 4 & Sep 22, 2005 & Jul 01, 2006 \\
\hline Gulf Cooperation Council (GCC) & Feb 23, 1994 & --- & --- & --- & Dec 31, 2001 & $\operatorname{Jan} 01,2003$ \\
\hline $\begin{array}{l}\text { Honduras - El Salvador and the Separate } \\
\text { Customs Territory of Taiwan, Penghu, } \\
\text { Kinmen and Matsu }\end{array}$ & May 27, 1997 & May 29, 2006 & Nov 24, 2006 & --- & May 07, 2007 & Mar 01, 2008 \\
\hline Hong Kong, China - New Zealand & Nov 09, 2000 & Jul 01, 2001 & Nov 01, 2009 & 5 & Mar 29, 2010 & Jan 01, 2011 \\
\hline Iceland - Faroe Islands & --- & --- & --- & --- & Sep 05, 2005 & Nov 01,2006 \\
\hline India - Afghanistan & --- & --- & --- & --- & Mar 06, 2003 & May 13,2003 \\
\hline India - Bhutan & --- & --- & --- & --- & Jul 28,2006 & Jul 29, 2006 \\
\hline India - Japan & Nov 29, 2004 & Jan 30, 2007 & Sep 09, 2010 & 14 & Feb 15, 2011 & Aug 01, 2011 \\
\hline India - Malaysia & Dec 20, 2004 & $\operatorname{Jan} 01,2008$ & Oct 27,2010 & 7 & Feb 18,2011 & Jul 01, 2011 \\
\hline India - Nepal & --- & --- & --- & --- & Dec 06, 1991 & Mar 06, 2002 \\
\hline India - SACU & --- & Oct 05, 2007 & --- & --- & --- & --- \\
\hline India - Singapore & Feb 04, 2003 & May 27,2003 & Mar 10, 2005 & 12 & Jun 29,2005 & Aug 01,2005 \\
\hline India - Sri Lanka & --- & Nov 16,1998 & --- & --- & Dec 28, 1998 & Dec 15,2001 \\
\hline Israel - Mexico & Feb 18, 1997 & Apr 01, 1998 & Feb 15, 2000 & 10 & Mar 06, 2000 & Jul 01, 2000 \\
\hline Japan - Australia & Apr 26, 2002 & Apr 24, 2007 & --- & --- & --- & --- \\
\hline Japan - Gulf Cooperation Council (GCC) & Apr 06, 2006 & Sep 21, 2006 & --- & --- & --- & --- \\
\hline Japan - Indonesia & Apr 12, 2005 & Jul 01, 2005 & Nov 28,2006 & 7 & Aug 20, 2007 & Jul 01, 2008 \\
\hline Japan - Korea, Republic of & Jun 07,2003 & Dec 01, 2003 & --- & $-\ldots$ & --- & --- \\
\hline Japan - Malaysia & Dec 11,2002 & Jan 13, 2004 & May 22, 2005 & --- & Dec 13, 2005 & Jul 13, 2006 \\
\hline Japan - Mexico & Jun 05, 2001 & Oct 27,2002 & Mar 05, 2004 & 14 & Sep 17,2004 & Apr 01, 2005 \\
\hline Japan - Philippines & Dec 11, 2003 & Feb 01, 2004 & Nov 29, 2004 & 8 & Sep 09, 2006 & Dec 11, 2008 \\
\hline Japan - Singapore & --- & Oct 22,2000 & Oct 20,2001 & 12 & $\operatorname{Jan} 13,2002$ & Nov 30,2002 \\
\hline Japan - Switzerland & Nov 01,2005 & May 14, 2007 & Sep 24, 2008 & 8 & Feb 19, 2009 & Sep 01, 2009 \\
\hline Japan - Thailand & Nov 20,2001 & Feb 16, 2004 & Feb 01, 2006 & 9 & Apr 03, 2007 & Nov 01,2007 \\
\hline Japan - Viet Nam & Dec 12, 2005 & Jan 16, 2007 & Sep 29, 2008 & 9 & Dec 25,2008 & Oct 01,2009 \\
\hline Jordan - Singapore & Jun 23,2003 & Oct 01,2003 & Apr 29, 2004 & 5 & May 16,2004 & Aug 22,2005 \\
\hline
\end{tabular}




\begin{tabular}{|c|c|c|c|c|c|c|}
\hline Korea, Republic of - Canada & Nov 19, 2004 & Jul 15, 2005 & --- & --- & --- & --- \\
\hline Korea, Republic of - Chile & Jun 01, 1998 & Sep 20, 1999 & Oct 24,2002 & 6 & Feb 15, 2003 & Apr 01, 2004 \\
\hline Korea, Republic of - India & Oct 04,2004 & Mar 23, 2006 & Sep 01, 2008 & 12 & Aug 07, 2009 & Jan 01, 2010 \\
\hline Korea, Republic of - Mexico & Apr 01, 2004 & Feb 02, 2006 & --- & --- & --- & --- \\
\hline Korea, Republic of - Singapore & Nov 14,2002 & $\operatorname{Jan} 27,2004$ & Nov 29,2004 & 7 & Aug 04, 2005 & Mar 02, 2006 \\
\hline Kyrgyz Republic - Armenia & --- & --- & --- & --- & Jul 04, 1994 & Oct 27, 1995 \\
\hline Kyrgyz Republic - Kazakhstan & --- & --- & --- & --- & Jun 22, 1995 & Nov 11, 1995 \\
\hline Kyrgyz Republic - Moldova & --- & --- & --- & --- & May 26, 1995 & Nov 21, 2006 \\
\hline Kyrgyz Republic - Russian Federation & --- & --- & --- & --- & Oct 08,1992 & Apr 24, 1993 \\
\hline Kyrgyz Republic - Ukraine & --- & --- & --- & --- & May 26, 1995 & $\operatorname{Jan} 19,1998$ \\
\hline Kyrgyz Republic - Uzbekistan & --- & --- & --- & --- & Dec 24, 1996 & Mar 20, 1998 \\
\hline $\begin{array}{l}\text { Latin American Integration Association } \\
\text { (LAIA) }\end{array}$ & --- & -- & --- & --- & Aug 12,1980 & Mar 18, 1981 \\
\hline MERCOSUR - India & Nov 01, 1999 & Apr 24, 2003 & --- & 4 & $\operatorname{Jan} 25,2004$ & Jun 01, 2009 \\
\hline $\begin{array}{l}\text { Mexico - Guatemala (Mexico - Northern } \\
\text { Triangle) }\end{array}$ & $\operatorname{Jan} 22,1991$ & Feb 16, 1996 & May 11,2000 & --- & Jun 29, 2000 & Mar 15, 2001 \\
\hline Mexico - Nicaragua & --- & Jan 11, 1991 & --- & -- & Dec 18, 1997 & Jul 01, 1998 \\
\hline New Zealand - Singapore & --- & Sep 11, 1999 & Aug 18,2000 & 6 & Nov 14,2000 & Jan 01, 2001 \\
\hline $\begin{array}{l}\text { Nicaragua and the Separate Customs } \\
\text { Territory of Taiwan, Penghu, Kinmen and } \\
\text { Matsu }\end{array}$ & --- & Sep 20, 2004 & --- & --- & Jun 16, 2006 & $\operatorname{Jan} 01,2008$ \\
\hline $\begin{array}{l}\text { North American Free Trade Agreement } \\
\text { (NAFTA) }\end{array}$ & Nov 13, 1979 & Feb 05, 1991 & Aug 12, 1992 & --- & Dec 17, 1992 & Jan 01, 1994 \\
\hline $\begin{array}{l}\text { Pacific Island Countries Trade Agreement } \\
\text { (PICTA) }\end{array}$ & Jun 01, 1999 & Aug 28,2000 & --- & --- & Aug 18, 2001 & Apr 13, 2003 \\
\hline Pakistan - China & Feb 20, 2004 & Apr 06, 2005 & Nov 13, 2006 & --- & Nov 24,2006 & Jul 01, 2007 \\
\hline Pakistan - Malaysia & --- & Feb 17, 2005 & Oct 01,2005 & 10 & Nov 08,2007 & Jan 01, 2008 \\
\hline Pakistan - Sri Lanka & May 02, 1999 & Jul 31, 2000 & --- & --- & Aug 01, 2002 & Jun 12, 2005 \\
\hline Pan-Arab Free Trade Area (PAFTA) & Sep 16, 1996 & Feb 19, 1997 & --- & --- & Dec 31, 1997 & Jan 01, 1998 \\
\hline Panama - Chile & --- & Nov 01, 1996 & Feb 02, 2006 & 15 & Jun 27,2006 & Mar 07, 2008 \\
\hline $\begin{array}{l}\text { Panama - Costa Rica (Panama - Central } \\
\text { America) }\end{array}$ & Jul 12, 1997 & Apr 27, 2000 & Jun 22, 2007 & 7 & Aug 07, 2007 & Nov 23, 2008 \\
\hline $\begin{array}{l}\text { Panama - El Salvador (Panama - Central } \\
\text { America) }\end{array}$ & Jul 12, 1997 & Apr 27, 2000 & $\operatorname{Jan} 13,2002$ & --- & Mar 06, 2002 & Apr 11, 2003 \\
\hline $\begin{array}{l}\text { Panama - Honduras (Panama - Central } \\
\text { America ) }\end{array}$ & Jul 12, 1997 & Apr 27, 2000 & Jun 15, 2007 & --- & --- & Jan 09, 2009 \\
\hline Panama - Singapore & Feb 17, 2004 & May 17, 2004 & Apr 08, 2005 & 3 & Mar 01, 2006 & Jun 24,2006 \\
\hline $\begin{array}{l}\text { Panama and the Separate Customs } \\
\text { Territory of Taiwan, Penghu, Kinmen and } \\
\text { Matsu }\end{array}$ & Aug 09, 2002 & Oct 03, 2002 & Aug 09, 2003 & 5 & Aug 21, 2003 & Jan 01, 2004 \\
\hline Peru - China & Jun 30,2004 & Jan 20, 2008 & Nov 19,2008 & 6 & Apr 28, 2009 & Mar 01, 2010 \\
\hline Peru - Korea, Republic of & Dec 01, 2002 & Mar 20, 2009 & Aug 30, 2010 & 5 & Mar 21, 2011 & Aug 01, 2011 \\
\hline Peru - Singapore & Nov 22, 2004 & Feb 14, 2006 & Aug 29, 2007 & 4 & May 28,2008 & Aug 01, 2009 \\
\hline Singapore - Australia & Nov 15,2000 & Feb 22, 2001 & Nov 03,2002 & 10 & Feb 17, 2003 & Jul 28, 2003 \\
\hline
\end{tabular}




\begin{tabular}{|c|c|c|c|c|c|c|}
\hline South Asian Free Trade Agreement (SAFTA) & Oct 19, 1993 & --- & --- & --- & Jan 06, 2004 & Jan 01, 2006 \\
\hline $\begin{array}{l}\text { South Asian Preferential Trade } \\
\text { Arrangement (SAPTA) }\end{array}$ & --- & --- & -- & 4 & Apr 12, 1993 & Dec 07, 1995 \\
\hline $\begin{array}{l}\text { South Pacific Regional Trade and Economic } \\
\text { Cooperation Agreement (SPARTECA) }\end{array}$ & --- & --- & --- & --- & Jul 14, 1980 & $\operatorname{Jan} 01,1981$ \\
\hline Southern African Customs Union (SACU) & --- & $\begin{array}{c}-- \\
\end{array}$ & $\begin{array}{ll}-- \\
\end{array}$ & --- & Oct 21, 2002 & Jul 15, 2004 \\
\hline $\begin{array}{l}\text { Southern African Development Community } \\
\text { (SADC) }\end{array}$ & --- & --- & -- & -- & Jul 17, 1992 & Sep 01, 2000 \\
\hline Southern Common Market (MERCOSUR) & --- & Jul 07, 1990 & --- & --- & Mar 26, 1991 & Dec 31, 1994 \\
\hline Switzerland - China & Apr 08, 2007 & Nov 07,2011 & --- & --- & --- & --- \\
\hline Thailand - Australia & Apr 06, 2001 & May 31,2002 & Oct 19,2003 & --- & Jul 05, 2004 & $\operatorname{Jan} 01,2005$ \\
\hline Thailand - New Zealand & Oct 20, 2003 & Jun 15,2004 & Dec 01, 2004 & --- & Apr 19, 2005 & Jul 01, 2005 \\
\hline $\begin{array}{l}\text { The Cross-Straits Economic Cooperation } \\
\text { Framework Agreement (ECFA) }\end{array}$ & --- & $\operatorname{Jan} 26,2010$ & 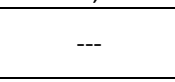 & --- & Jun 29, 2010 & --- \\
\hline $\begin{array}{l}\text { Trans-Pacific Strategic Economic } \\
\text { Partnership }\end{array}$ & Oct 28, 2002 & Sep 24, 2003 & Jun 03, 2005 & -- & Jul 18, 2005 & May 28, 2006 \\
\hline Turkey - Albania & --- & --- & --- & --- & Dec 22, 2006 & May 01, 2008 \\
\hline Turkey - Bosnia and Herzegovina & Aug 29,2000 & --- & --- & --- & Jul 03, 2002 & Jul 01, 2003 \\
\hline Turkey - Chile & --- & Nov 01,2007 & Mar 20, 2009 & 4 & Jul 14, 2009 & Mar 01, 2011 \\
\hline Turkey - Croatia & --- & --- & Nov 30,2001 & --- & Mar 13, 2002 & Jul 01, 2003 \\
\hline $\begin{array}{l}\text { Turkey - Former Yugoslav Republic of } \\
\text { Macedonia }\end{array}$ & --- & --- & --- & -- & Sep 07, 1999 & Sep 01, 2000 \\
\hline Turkey - Georgia & --- & Feb 01, 2007 & --- & --- & Nov 21, 2007 & Nov 01, 2008 \\
\hline Turkey - Israel & --- & Sep 01, 1994 & --- & --- & Mar 14, 1996 & May 01, 1997 \\
\hline Turkey - Jordan & Mar 19, 2001 & Jul 17, 2007 & --- & --- & Dec 01, 2009 & Mar 01, 2011 \\
\hline Turkey - Montenegro & --- & --- & --- & --- & Nov 26,2008 & Mar 01, 2010 \\
\hline Turkey - Morocco & --- & Feb 15, 1999 & Oct 03,2003 & --- & Apr 07, 2004 & Jan 01, 2006 \\
\hline Turkey - Palestinian Authority & --- & --- & --- & --- & Jul 20, 2004 & Jun 01, 2005 \\
\hline Turkey - Serbia & --- & --- & --- & --- & Jun 01, 2009 & Sep 01, 2010 \\
\hline Turkey - Syria & --- & --- & --- & --- & Dec 22, 2004 & $\operatorname{Jan} 01,2007$ \\
\hline Turkey - Tunisia & May 19,2003 & --- & Sep 28, 2004 & --- & Nov 25,2004 & Jul 01, 2005 \\
\hline US - Australia & Mar 25, 2001 & Mar 17, 2003 & Feb 08, 2004 & 5 & May 18,2004 & Jun 01, 2005 \\
\hline US - Bahrain & May 22,2003 & Jan 26, 2004 & May 27, 2004 & --- & Sep 14, 2004 & Aug 01, 2006 \\
\hline US - Chile & Aug 09, 1999 & Dec 06, 2000 & Dec 11, 2002 & 14 & Jun 06, 2003 & $\operatorname{Jan} 01,2004$ \\
\hline US - Israel & --- & --- & --- & --- & Apr 22, 1985 & Aug 19,1985 \\
\hline US - Jordan & Jul 24, 1998 & Jun 06,2000 & $-\ldots$ & --- & Oct 24,2000 & Dec 17, 2001 \\
\hline US - Morocco & $\operatorname{Jan} 23,2002$ & Jan 21, 2003 & Mar 02, 2004 & 8 & Jun 15,2004 & Jan 01, 2006 \\
\hline US - Oman & Jul 05, 2004 & Mar 15, 2005 & Oct 03,2005 & --- & Jan 19, 2006 & $\operatorname{Jan} 01,2009$ \\
\hline US - Panama & Nov 18,2003 & Apr 26, 2004 & Dec 16, 2006 & --- & Jun 28,2007 & --- \\
\hline US - Peru & Nov 18,2003 & May 18,2004 & Dec 07, 2005 & 13 & Apr 12, 2006 & Feb 01, 2009 \\
\hline US - Singapore & Nov 16,2000 & Dec 04, 2000 & Nov 19, 2002 & 11 & May 06, 2003 & Jan 01, 2004 \\
\hline Ukraine - Azerbaijan & --- & --- & --- & --- & Jul 28, 1995 & Sep 02, 2006 \\
\hline Ukraine - Belarus & --- & --- & --- & --- & Oct 19, 2005 & Nov 11, 2006 \\
\hline
\end{tabular}




\begin{tabular}{|c|c|c|c|c|c|c|}
\hline Ukraine - Kazakhstan & --- & --- & --- & --- & Sep 17, 1994 & Oct 19,1998 \\
\hline Ukraine - Moldova & --- & --- & --- & --- & Nov 13, 2003 & May 19, 2005 \\
\hline Ukraine - Russian Federation & --- & --- & Jun 19, 1993 & --- & Jun 24,1993 & Feb 21, 1994 \\
\hline Ukraine - Singapore & --- & May 08, 2007 & --- & --- & --- & --- \\
\hline Ukraine - Tajikistan & --- & --- & --- & --- & Jul 06, 2001 & Jul 11, 2002 \\
\hline Ukraine - Uzbekistan & --- & --- & Oct 22, 1993 & --- & Dec 29, 1994 & Jan 01, 1996 \\
\hline Ukraine -Turkmenistan & 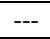 & --- & --- & --- & Nov 05, 1994 & Nov 04, 1995 \\
\hline
\end{tabular}

